\title{
Diabetic Complications: A Natural Product Perspective
}

Dpen Access

\author{
S. N. C. Sridhar, Sushma Kumari and Atish T. Paul* \\ Laboratory of Natural Drugs, Department of Pharmacy, Birla Institute of Technology and Science (BITS Pilani), Pilani \\ campus, Pilani-333031 (Rajasthan), India
}

\begin{abstract}
Diabetes is a chronic disease that affects over 400 million people globally. With 5.5\% increase in diabetes related deaths in 2010, as compared to the 2007 and World Health Organisation's projection of diabetes as the $7^{\text {th }}$ leading cause of death by 2030, has dazed the current drug discovery fraternity. The major focus of drug discovery has been towards the control of hyperglycemia while the severe complications arising due to it have been overlooked. Plant based natural products (pure phytochemicals or in the form of crude extracts) have been the mainstay of drug discovery program for treatment of numerous human diseases. In addition, indigenous systems of medicines like Ayurveda and Traditional Chinese Medicine (TCM) possess a rich plethora of knowledge about clinically used medicinal plants for controlling the diabetic complications. With India becoming the capital of diabetes and its associated complications, the present natural products perspective is more evident and highlights the current natural products based research that has been done for the last five years in tackling diabetic complications.
\end{abstract}

Keywords: Cardiovascular disease, diabetes, diabetic complications, natural products, nephropathy, neuropathy, retinopathy.

\section{INTRODUCTION}

Diabetes is defined as "a chronic disease that occurs either when the pancreas does not produce enough insulin or when the body cannot effectively use the insulin it produces" [1]. Hyperglycaemia, or raised blood sugar, is a common effect of uncontrolled diabetes and with time, this leads to serious damage to many of the body systems, especially the nerves and blood vessels. Globally, 382 million people were detected with diabetes in 2013, and the number is expected to project to 592 million by 2035 . The severity of diabetes is more in low and middle income countries with $80 \%$ of the population contributing to the global statistics [2]. Close to four million deaths in the age group of 20-79 were recorded due to diabetes in 2010, accounting for $6.8 \%$ of global allcause mortality in this age group. There has been a $5.5 \%$ increase in diabetic deaths in 2010, as compared to the 2007 statistics [3]. Another problem associated with diabetes is that the increase in blood glucose level may lead to severe complications that affect various systems of the body. These complications are divided into two types. Microvascular complications include eye disease or "retinopathy", kidney disease termed "nephropathy", and neural damage or "neuropathy". The major macrovascular complication includes accelerated cardiovascular disease resulting in myocardial infarction and cerebrovascular disease manifesting as strokes [4]. Diabetic retinopathy and cardiovascular disease are one among the leading causes of blindness and deaths, respectively.

Medicinal plants have been an integral part of human healthcare systems for centuries. They have been used either

\footnotetext{
*Address correspondence to this author at the 3121D, Department of Pharmacy, Birla Institute of Technology and Science (BITS Pilani), Pilani campus, Pilani-333031 (Rajasthan), India; Tel: +91 1596515814 ;

Fax:+91 1596 244183; E-mail: atish.paul@pilani.bits-pilani.ac.in
}

in the form of pure phytochemicals (e.g. taxol, artemisinin etc.) or crude extracts (single or combinations) for the treatment of various diseases. Also there has been an increasing importance in the utilization of plant based natural products, commercially due to their lower side effects as compared to the synthetic drugs. The contribution of plant based therapeutics for treatment of diabetes has been very valuable and the vast plethora of research articles being published makes it more evident. With India becoming the diabetic capital of the world and with still a lot of uncertainty over the other subclass of diabetes like Type 1.5 (Latent Autoimmune Diabetes in Adults, LADA), it became imperative to discover and develop newer, safer and effective antidiabetic therapeutics which will not only control diabetes but also its associated complications. The present review discusses about the various natural products that have been investigated for their potential to prevent or ameliorate various diabetic complications during the last five years. This review is an attempt to channelize the available research data to add value to natural products in the area of diabetic complications.

\section{DIABETIC EYE DISEASES}

Diabetic eye diseases include cataract (where the eye lens is clouded), glaucoma (where the fluid pressure inside the eye increases leading to optic nerve damage) and diabetic retinopathy (where the blood vessels of the retina are damaged) [5]. Diabetic retinopathy is the most common disease among all the diabetic complications and is characterized by a spectrum of lesions within the retina. The first stage (Mild Nonproliferative Retinopathy) starts with the occurrence of microaneurysms, small outpouchings from retinal capillaries, and dot intraretinal haemorrhages. As the disease progresses to the second stage (Moderate Nonproliferative Retinopathy), there is an increase in the number and size of intraretinal haemorrhages. This increase may be accompanied by 
cotton-wool spots which indicate regional failure of the retinal microvascular circulation resulting in ischemia. Further progression of the disease leads to Severe Proliferative Diabetic Retinopathy where the retina sends signals to the brain for the development of new blood vessels. This leads to the final stage (Proliferative Retinopathy) which involves the formation of new blood vessels that develop from the retinal circulation $[5,6]$. These new vessels can extend into the vitreous cavity of the eye and can lead to haemorrhages into the vitreous, resulting in vision loss. Another important change that can occur is the diabetic macular oedema, which involves the breakdown of the blood-retinal barrier, with leakage of plasma from small blood vessels in the macula, the central portion of the retina that is responsible for the major part of visual function. This causes swelling of the retina [6]. It is the leading cause of blindness among adults aged 20-74 years.

Hence prevention of diabetic eye diseases by targeting different pathways and enzymes via strategies like inhibiting the production of Advanced Glycation End products (AGEs), down regulation of inflammatory mediators, Interleukins (ILs), Cyclooxygenase-2 (COX-2), Vascular Endothelial Growth Factor (VEGF), prevention of oxidative stress through anti-oxidant activity, and inhibition of certain enzymes like Aldose reductase (AR) are needed. Various pure natural products and plant extracts have been reported to prevent or delay the progression of diabetic eye diseases and are summarized below.

\section{Pure Compounds}

Various pure phytochemicals have been tested in different cell cultures, in vitro and in vivo studies for their potential in treatment of diabetic retinopathy (See Fig. 1) and are described below.

Epigallocatechin-3-gallate (EGCG) (1): EGCG is one of the major polyphenols isolated from Camellia sinensis (L.) Kuntze. (Theaceae). It was found by Ye et al. to exhibit protective effect against high glucose-induced apoptosis in $\mathrm{Hu}-$ man lens epithelial B-3 cells by decreasing the expression of Bcl-2/Bax (B-cell lymphoma 2/Bcl-2 associated X), c-fos (A murine fos proto-oncogene), c-myc (A cellular homolog gene of the v-myc oncogene) and p53 (A tumour suppressor protein), when the cells were pre-incubated with EGCG at concentrations of $25-50 \mu \mathrm{M}$, thus proving beneficial in prevention of diabetic cataract formation [7].

Astragaloside IV (2): It is a bioactive principle mainly found in the genus Astragalus (Fabaceae). Hao et al. found that the compound exhibited a protective effect on retinal ganglion cells-5 against high-glucose induced damage by elevation of mitochondrial membrane potential and alleviation of mitochondrial swelling. The cell survival rates were found to be $81.6 \%, 80.0 \%$ at concentrations of 100,200 $\mathrm{mg} / \mathrm{L}$ of astragaloside IV respectively [8].

Resveratrol (3): It is a phytoalexin found in wine grapes infected by the fungus Botrytis cinerea De Bary. Whetzel. (Sclerotiniaceae). Spontaneously arising retinal pigment epithelial (ARPE-19) cells incubated with $33 \mathrm{mM}$ glucose in the presence of $0-10 \mu \mathrm{M}$ trans-resveratrol was found by Losso et al. to dose dependently inhibit VEGF, transforming growth factor (TGF)- $\beta 1, \mathrm{COX}-2$, IL-6, IL-8 accumulation,
Protein kinase $\mathrm{C}$ (PKC)- $\beta$ activation, Connexion 43 degradation and enhanced Gap junction intercellular communication [9]. In another study it was found by Srivastava et al. that resveratrol regulated Forkhead box $\mathrm{O}(\mathrm{FOXO})$ transcription factors at concentrations ranging from 10-20 $\mu \mathrm{M}$ determined through luciferase assay and suggested to be useful in treatment of diabetic retinopathy [10].

Ginsenoside $\boldsymbol{R b 2}$ (4): It is a steroidal constituent isolated from genus Panax (Araliaceae). Park et al. found that Ginsenoside $\mathrm{Rb} 2$ exhibited its protective effect against diabetic retinopathy by prevention of high glucose-induced apoptosis through decreasing Bcl-2 expression, lipid peroxide (LPO) and COX-2 expression, and increasing Bax expression in ARPE-19 cells at a concentration of $1 \mu \mathrm{g} / \mathrm{mL}$ [11].

3,5-Di-O-caffeoyl-epi-quinic Acid (5): It is isolated from the leaves and stems of Erigeron annuus L. Pers. (Compositae). It was found by Jang et al. to inhibit the formation of AGEs and rat lens aldose reductase (RLAR) with $\mathrm{IC}_{50}$ values of $6.06 \mu \mathrm{M}$ and $0.44 \mu \mathrm{M}$ respectively, along with AGEsbovine serum albumin cross-linking to collagen and prevented opacification of rat lenses [12].

Puerariafuran (6): It is a 2-arylbenzofuran isolated from the roots of Pueraria lobata Ohwi. (Fabaceae). Kim et al. found that Puerariafuran potently inhibited RLAR with an $\mathrm{IC}_{50}$ value of $22.34 \mu \mathrm{M}$. The xylose induced opacity of lenses was significantly improved, and there was a significant increase in the reduced glutathione (GSH)/oxidized glutathione (GSSG) ratio, superoxide dismutase (SOD) and catalase (CAT) activity in rat lenses on treatment with puerariafuran $(3-15 \mu \mathrm{M})$ [13].

Scopoletin (7) and Tiliroside (8): Scopoletin is a coumarin, while Tiliroside is a phenolic compound. Both the compounds were isolated from the flower buds of Magnolia fargesii Cheng. (Magnoliaceae) and investigated for their RLAR and AGEs inhibitory activity by Lee et al. Scopoletin inhibited AGEs formation with $\mathrm{IC}_{50}$ value of $2.93 \mu \mathrm{M}$ and showed a significant RLAR inhibition with $\mathrm{IC}_{50}$ value of $22.5 \mu \mathrm{M}$. Scopoletin significantly inhibited cataractogenesis of rat lenses induced with xylose in ex vivo experiments in dose dependent manner. Tiliroside exhibited potent inhibitory activity against RLAR with an $\mathrm{IC}_{50}$ of $14.9 \mu \mathrm{M}$ [14].

$\boldsymbol{\beta}$-Glucogallin (9): It is 1-O-galloyl- $\beta$-D-glucose found in Phyllanthus emblica L. (Phyllanthaceae). Puppala et al. found potent inhibition of $\mathrm{AR}$ in vitro $\left(\mathrm{IC}_{50}\right.$ value of $\left.17 \mu \mathrm{M}\right)$ and sorbitol accumulation by $73 \%$ at $30 \mu \mathrm{M}$ under hyperglycemic conditions in an ex-vivo organ culture model of lenses excised from transgenic mice over expressing human AR [15].

Arctiin (10): It is isolated from dry seeds of Arctium lappa L. (Asteraceae). Treatment of Streptozotocin (STZ) induced diabetic male Sprague-Dawley (SD) rats with arctiin (30, 90 or $270 \mathrm{mg} / \mathrm{kg}$ body weight (b.w)/day p.o. for sixteen weeks) was found by Lu et al. to ameliorate retinal oedema, detachment of the retina, and VEGF expression in the retina. Increase in the viability of retinal microvascular endothelial cells in vitro at concentrations ranging from $10 \mu \mathrm{g} / \mathrm{mL}$ to 100 $\mathrm{mg} / \mathrm{mL}$ was also found using MTT assay signifying the importance of this compound as an inhibitor of diabetic retinopathy [16]. 
<smiles>O=C(O[C@H]1Cc2c(O)cc(O)cc2O[C@H]1c1cc(O)c(O)c(O)c1)c1cc(O)c(O)c(O)c1</smiles>

1

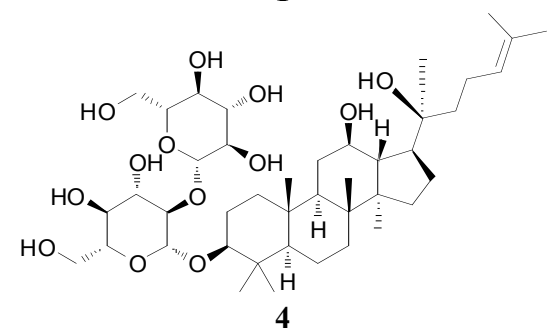<smiles>COc1cc2ccc(=O)oc2cc1O</smiles>

7

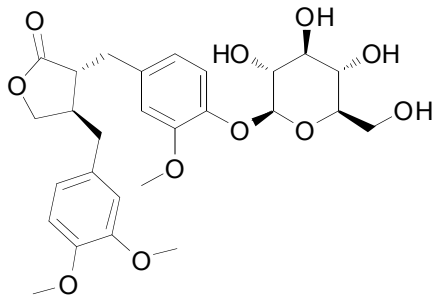

10

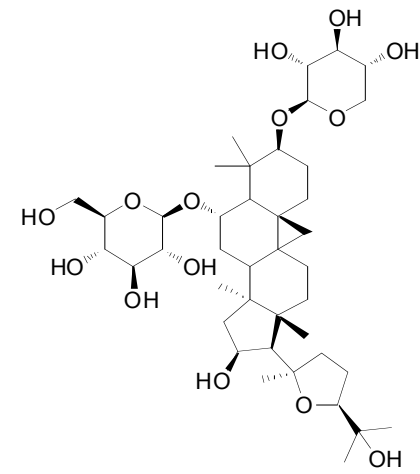

2<smiles>O=C(/C=C/c1ccc(O)c(O)c1)O[C@H]1CC(O)(C(=O)O)C[C@H](OC(=O)/C=C/c2ccc(O)c(O)c2)C1O</smiles>

5<smiles>O=C(/C=C/c1ccc(O)cc1)Oc1c(O)cc(O)c2c(=O)c(OC3O[C@H](CO)[C@@H](O)[C@H](O)[C@H]3O)c(-c3ccc(O)cc3)oc12</smiles>

8

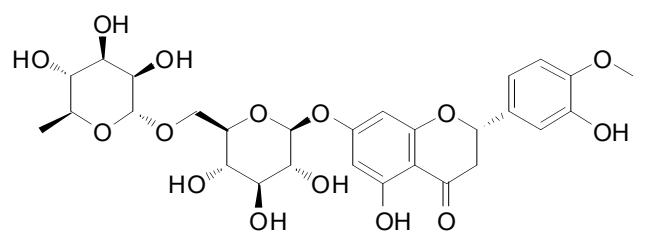

11<smiles>Oc1ccc(/C=C/c2cc(O)cc(O)c2)cc1</smiles>

3<smiles>COc1cc(O)ccc1-c1oc2cc(O)ccc2c1C=O</smiles><smiles>O=C(O[C@H]1O[C@H](CO)[C@@H](O)[C@H](O)C1O)c1cc(O)c(O)c(O)c1</smiles><smiles>NCCS(=O)(=O)O</smiles>

12

Fig. (1). Structures of phytochemicals (1-12) active against diabetic retinopathy.

Hesperidin (11): It is a flavonone glycoside abundantly found in citrus fruits. Administration of hesperidin (100, 200 $\mathrm{mg} / \mathrm{kg}$ b.w/day i.g.) for 12 weeks to STZ induced male SD rats was found by Shi et al. to suppress blood-retina breakdown and increased retinal thickness. It also reduced AR activity, retinal tumour necrosis factor (TNF)- $\alpha$, Intercellular adhesion molecule (ICAM)-1, VEGF and IL-1 $\beta$. It significantly reduced the plasma malondialdehyde (MDA) levels and increased the SOD activity [17].

\section{Extracts}

Table 1 summarizes list of plants and their extracts reported to have protective effect in diabetic eye diseases.

\section{Miscellaneous}

Lycium barbarum, Taurine (12) and Chrysanthemum morifolium: Song et al. found that the fruit of Lycium bar- barum L. (Solanaceae) and Taurine prevented diabetic retinopathy progression by enhanced expression of Peroxisome proliferator activated receptor (PPAR $\gamma$ ) mRNA and protein. It dose-dependently $(0.1,0.5$ and $1 \mathrm{mg} / \mathrm{mL})$ enhanced PPAR $\gamma$ luciferase activity in human embryonic kidney-293 cell line transfected with PPAR- $\gamma$ reporter gene. It also dose dependently $(0.1 \mathrm{mg} / \mathrm{mL}, 0.5 \mathrm{mg} / \mathrm{mL}$ and $0.75 \mathrm{mg} / \mathrm{mL})$ down-regulated mRNA of pro-inflammatory mediators encoding matrix metalloproteinase (MMP)-9, Fibronectin (FN) and the protein expression of $\mathrm{COX}-2$ and inducible nitric oxide synthase (iNOS) proteins in an inflammation exposing ARPE-19 cells to high glucose [28]. In another study by $\mathrm{Hu}$ et al. on STZ induced male SD rats, aqueous decoction of dried fruits of L. barbarum and Chrysanthemum morifolium Ramat. (Asteraceae) were administered alone and in combination (5 g/kg b.w/day p.o.) for eight weeks. In Lycium treated rats, reduction of electroretinogram b-wave was reversed after diabetic induction and was suggested to be due 
Table 1. Plants and their extracts reported to have protective effect in diabetic eye diseases.

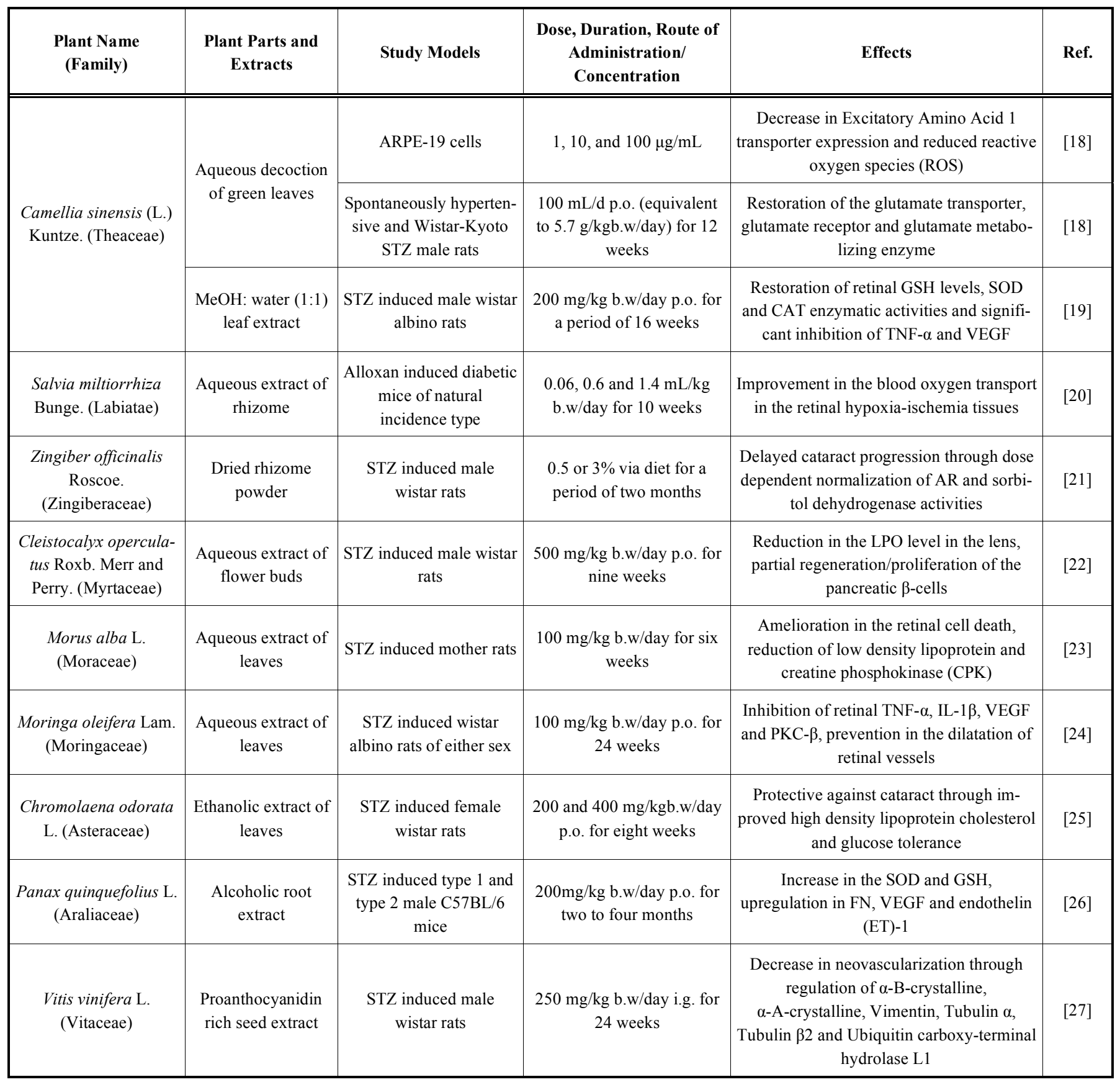

to anti-apoptotic effects on neurons and retinal ganglion cells respectively. Chrysanthemum treatment did not prevent decrease of a-wave amplitude after diabetes induction indicating its ineffectiveness; however treatment with a mixture of Lycium and Chrysanthemum showed a significant protective effect and prevention of the a-wave amplitude loss similar to that achieved by insulin treatment [29].

\section{CARDIOVASCULAR DISEASES}

Cardiovascular diseases include a spectrum of complications which arise from endothelial dysfunction, oxidation, inflammation, and vascular remodelling, leading to atherogenesis. This might progress into a coronary blockade, ulti- mately resulting into diabetic heart disease. Diabetic heart disease may also arise due to high glucose induced hypertension or due to a direct effect of diabetes on myocardium, termed as diabetic cardiomyopathy. Altered metabolism in diabetes leads to reduced glucose and pyruvate utilisation, increased free fatty acid oxidation, accumulation of nonchain acyl carnitines, and reduced glucose transporter type 4 (Glut-4) expression. These features when combined, result in impaired oxidative phosphorylation and myocardial oxygen demand. As a result, it leads to reduced myocardial performance, morphological changes and apoptosis. The morphological changes in the myocardium include increased fibrosis due to increase in angiotensin (Ang) II and its receptors, which induces myocyte fibrosis. Activation of PKC results 
in the binding of the AGEs to their receptors leading to induction of nuclear factor, proinflammatory cytokines, inflammation, growth factor release, and fibrosis [30].

In an attempt of preventing or reducing the diabetic cardiovascular complications, many phytochemicals and crude plant extracts have been screened for their potential which are summarized below.

\section{Pure Compounds}

Various pure phytochemicals (Fig. 2) tested in different cell culture and in vivo studies for their potential in treatment of diabetic cardiovascular disease are described below.

EGCG (1): In a study conducted by Yang et al., EGCG $(10,30$, and $50 \mu \mathrm{M})$ was found to suppress the high glucose induced proliferation of vascular smooth muscle cells (VSMC) as determined by MTT assay. EGCG inhibited PKC and extracellular signal-regulated kinase (ERK) $1 / 2$ signalings, which resulted in an attenuation of its downstream transcription factor, Elk-1 (ETS domain-containing protein) phosphorylation [31]. In another study by $\mathrm{Yu}$ et al., EGCG $(40 \mu \mathrm{M})$ was found to attenuate the down regulation of the cardiac gap junction in rat cardiomyocytes induced by high glucose through activation of time dependent phosphorylated ERK, c-Jun-N-terminal kinase (JNK) and p38 mitogen activated protein kinase (MAPK) pathways [32].

Astragaloside IV (2): Yuan et al. found that the compound inhibited the proliferation of VSMC induced apoptosis by 11.1 and $14.0 \%$ respectively at concentrations of 5 and $50 \mu \mathrm{g} / \mathrm{mL}$ under high glucose conditions (25 mM) accompanied with typical morphological alterations and loss of mitochondrial membrane potential. It also increased the expression of $\alpha$-smooth muscle actin ( $\alpha$-SMA) [33].

5-hydroxymethylfurfural (13): It has been isolated from processed Cornus officinalis Torr. ex Dur. (Cornaceae) by Cao et al., where they found that in concentrations of 100 , 200 , and $400 \mu \mathrm{M}$ it prevented high glucose-induced oxidative stress and expression of JNK1 and JNK2/3 in human umbilical vein endothelial cells (HUVECs). It also inhibited high glucose-induced activation of IL-8 [34].

Oleanolic Acid (14): It is an active constituent of Syzygium aromaticum L. Merrill \& Perry. (Myrtaceae). Mapanga et al. found that it dulled the hyperglycemia induced contractile dysfunction, attenuated the high glucose induced oxidative stress and apoptosis at 20 and $50 \mu \mathrm{M}$ concentrations in H9C2 cardiac myoblasts. It also decreased hexosamine biosynthetic pathway flux and proteasomal activity following ischemic reperfusion. It decreased SOD activity in simulated acute hyperglycemic hearts following an ischemic insult. Two week treatment with $0.45 \mathrm{mg} / \mathrm{kg}$ b.w/day i.v. also improved heart function in STZ induced male wistar rats [35].

Icariin (15): It is a flavonoid isolated from Epimedium grandiflorum C. Morren. (Berberidaceae). Bao et al. found that administration of Icariin (30 and $120 \mathrm{~mL} / \mathrm{kg} \mathrm{b.w} /$ day i.g.) for eight weeks to female SD rats was found to reduce mitochondrial oxidative stress injury in diabetic hearts. It also reduced the ratio of ventricular weight and body weight, increased the left ventricular systolic pressure and left ventricular end diastolic pressure in diabetic rats. Reduction in the myocardial collagen and the level of cardiac mitochon- drial ROS along with decrease in the mitochondrial MDA level and increased SOD activity was also found [36].

Genistein (16): It is an isoflavone, majorly found in Glycine $\max \mathrm{L}$. (Fabaceae). It was investigated by Palanisamy et al. that genistein lowered blood pressure (BP), restored Angiotensin converting enzyme (ACE) and endothelial nitric oxide synthase (eNOS) expression through activation of PKC- $\beta$ II in fructose fed hypertensive male wistar rats administered with $1 \mathrm{mg} / \mathrm{kg} \mathrm{b.w} /$ day of genistein [37].

Breviscapine (17): It is a flavonoid extracted from Erigeron breviscapus Vant. Hand-Mazz. (Compositae). Wang et al. found that administration of Breviscapine twice a day (10 and $25 \mathrm{mg} / \mathrm{kg}$ b.w/day i.g.) for six weeks in STZ induced male SD rats ameliorated cardiac dysfunction and regulated the myocardial $\mathrm{Ca}^{2+}$-cycling proteins. It decreased the expression and activity of PKC- $\alpha$ and PKC- $\beta 2$ by inhibiting the over-expression of PKC. It also decreased the expression of phospholamban in diabetic rats and increased the expression of protein phosphatase inhibitor-1, sarco/endoplasmic reticulum $\mathrm{Ca}^{2+}$-ATPase and Ryanodine receptor [38].

Phlorizin (18): It is a compound isolated from genus Malus (Rosaceae) commonly called as apples. Lin et al. found that the administration of Phlorizin $(20 \mathrm{mg} / \mathrm{kg} \mathrm{b} . \mathrm{w} /$ day i.g.) to male $\mathrm{C} 57 \mathrm{BLKS} / \mathrm{J} \mathrm{db} / \mathrm{db}$ and $\mathrm{db} / \mathrm{m}$ mice for 10 weeks ameliorated vascular complications. It blocked the intestinal glucose absorption through inhibition of the sodium-glucose symporters (SGLT) located in the proximal renal tubule (SGLT2) and mucosa of the small intestine (SGLT1), which reduced plasma glucose levels. The vascular wall of the untreated diabetic group was found to be thickened with impaired intima and a narrowed lumen. Also the migration of VSMC into the elastic laminar, and an increase of heterochromatin was found. With phlorizin treatment, these microand ultra-structure changes were less severe [39].

Rosmarinic acid (19): It is natural phenolic acid found in Rosmarinus officinalis L. (Lamiaceae). Sotnikova et al. found that administration of rosmarinic acid $(50 \mathrm{mg} / \mathrm{kg}$ b.w/day p.o.) to STZ induced male wistar rats attenuated diabetes induced vascular dysfunction of the rat aorta. Aortic dysfunction due to structural alterations of endothelium and decreased endothelium dependent relaxation accompanied by overexpression of IL- $1 \beta$, TNF- $\alpha$, preproendothelin- 1 and endothelin converting enzyme-1 antioxidant and antiinflammatory effects was found to be ameliorated [40].

\section{Extracts}

Table 2 summarizes list of plants and their extracts reported to have protective effect in diabetic cardiovascular disease as investigated through various cell culture and in vivo studies

\section{Miscellaneous}

Kalpaamrutha: It is a modified indigenous Siddha preparation found to be anti-inflammatory on myocardium of STZ induced male SD rats by Raja et al., where they have investigated reduction in Plasma $\mathrm{C}$ - reactive protein (CRP), iNOS, COX-2, IL-1 $\beta$ and IL-6, TNF- $\alpha$ NF-kB and expressions of MMP-2 and MMP-9; increase in eNOS and nucleotide 
$\mathrm{HO}$<smiles>Cc1ccc(C=O)o1</smiles>

13

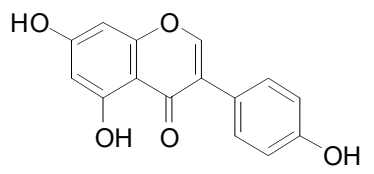

16

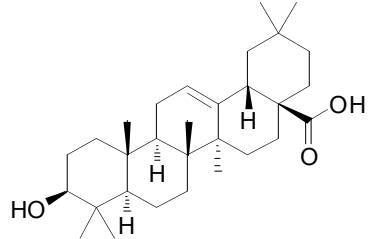

14<smiles>O=C(O)[C@H]1O[C@H](Oc2cc3oc(-c4ccc(O)cc4)cc(=O)c3c(O)c2O)[C@H](O)[C@@H](O)[C@H]1O</smiles>

17

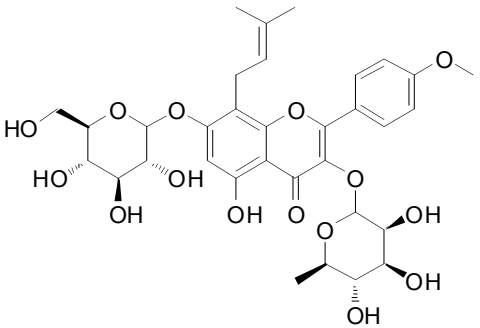

15<smiles>O=C(CCc1ccc(O)cc1)c1c(O)cc(O)cc1O[C@@H]1O[C@H](CO)[C@@H](O)[C@H](O)[C@H]1O</smiles>

18<smiles>O=C(/C=C/c1ccc(O)c(O)c1)OC(Cc1ccc(O)c(O)c1)C(=O)O</smiles>

19

Fig. (2). Structures of phytochemicals (13-19) active against diabetic cardiovascular disease.

Table 2. Plants and their extracts reported to have protective effect in diabetic cardiovascular disease.

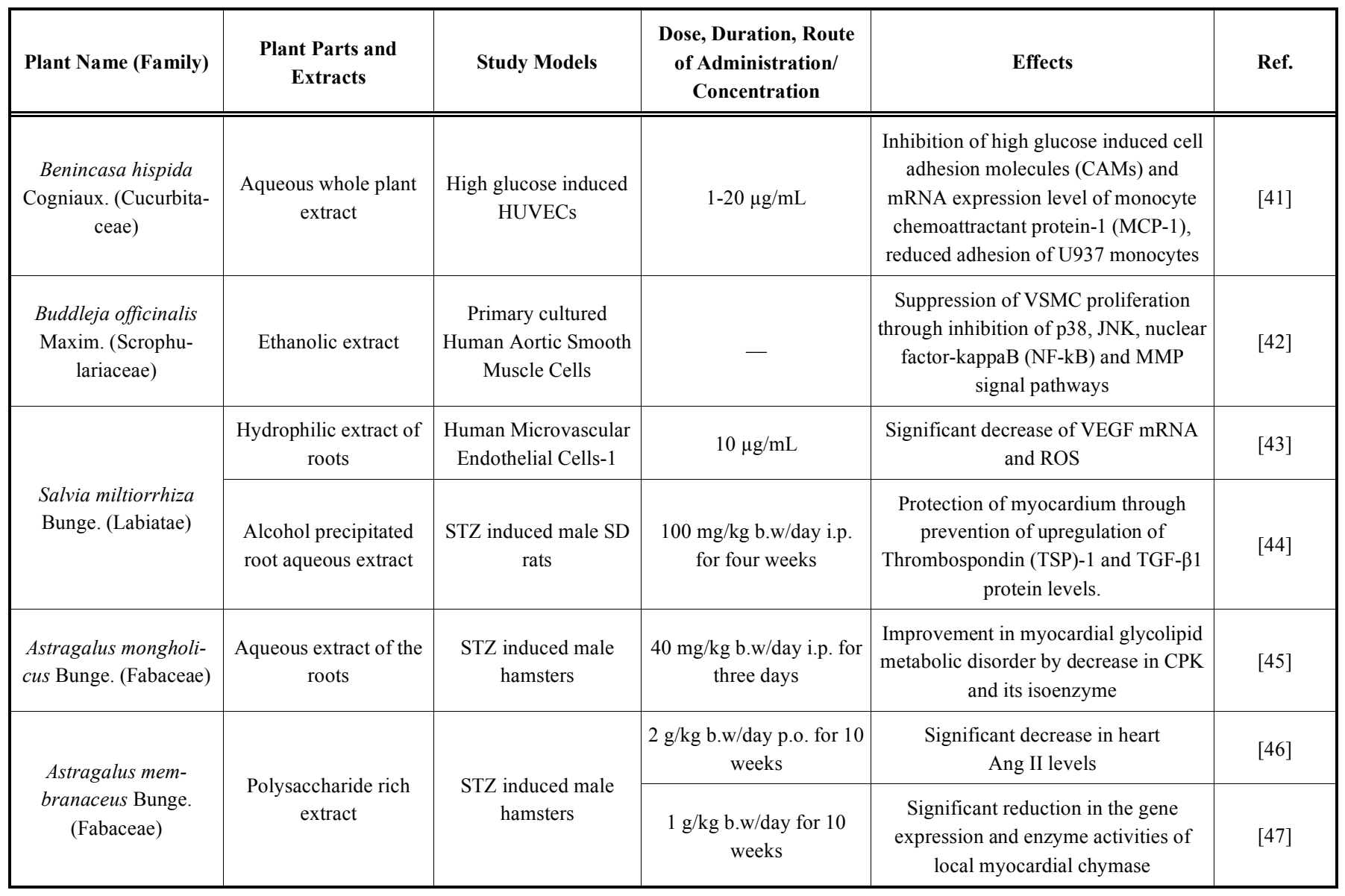


(Table 2) contd....

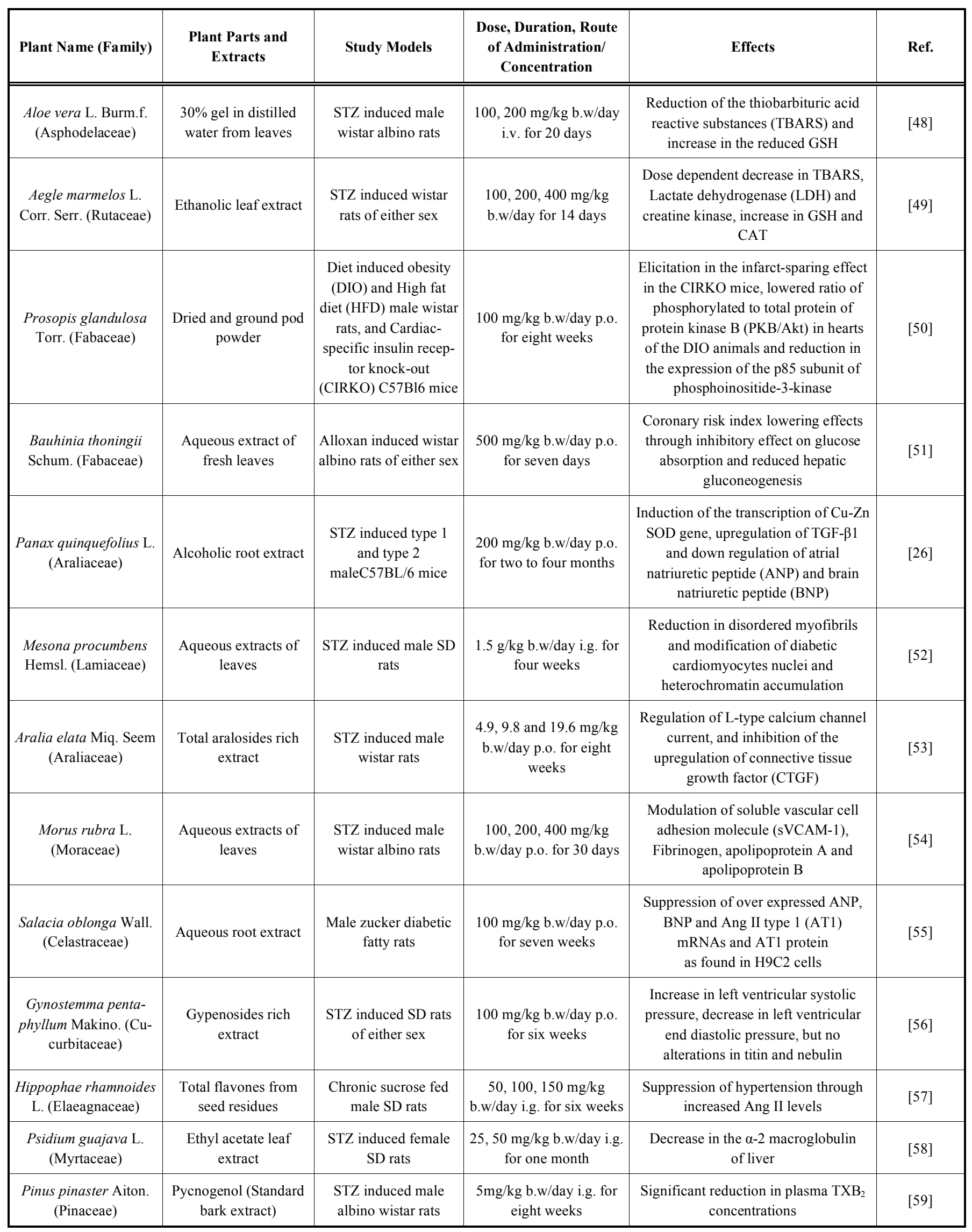


adenine diphosphate (NADPH) oxidase mRNA expressions when administered with $200 \mathrm{mg} / \mathrm{kg}$ b.w/day p.o. for four weeks [60, 61].

Shengmai powder and Danshen decoction: Jie et al. assessed the protective effect of Shengmai San alone [62] as well as a mixture $(7.125 \mathrm{~g} / \mathrm{kg}$ b.w/day p.o.) of Shengmai powder and Danshen Decoction [63] in STZ induced male SD rats in two different studies conducted for 12 weeks and nine weeks respectively. They found a decrease in the expression levels of TSP-1 mRNA, Tribbles homolog (TRB)-3 mRNA, chymase, Active and Latent-TGF- $\beta 1$ protein in both the studies.

\section{DIABETIC NEUROPATHY}

Diabetic neuropathy is a microvascular complication which is linked to the autonomous nervous system but spinal cord and central nervous system may also be involved, which might result in impairment in wound healing, erectile dysfunction, and cardiovascular dysfunction. Symptoms such as vascular abnormalities and improved nerve conduction velocities are proposed to be a result of increase in neuronal blood flow. In the advanced stages, nerve fibre deterioration may take place through apoptosis which results in altered sensitivities to vibrations and thermal thresholds, gradually leading to loss of sensory perception [4].

\section{Pure Compounds}

Various pure phytochemicals have been tested in different in vitro, cell culture and in vivo studies for their potential in treatment of diabetic neuropathy (See Fig. 3) and are described below.

$\boldsymbol{E} \boldsymbol{G C G}$ (1): Romeo et al. found that EGCG at doses of $10-200 \mu \mathrm{M}$ induced heme oxygenase (HO-1) in rat neurons (H 19-7) and acted as a cytoprotective agent against oxidative stress damage in immortalized rat neurons. Activation of the transcription factor Nrf2 was proposed to be the mechanism for the induction [64].

Tanshinone IIA (20): It is a major component of Salvia miltiorrhiza Bunge. (Lamiaceae). Liu et al. investigated its neuroprotective effect by administering 20,50 and 100 $\mathrm{mg} / \mathrm{kg}$ b.w/day i.p. to STZ induced male SD albino rats for four weeks. Parameters like thermal and mechanical nociceptive threshold, motor nerve conducting velocity (MNCV), levels of SOD, CAT and MDA in sciatic nerve were alleviated [65].

Naringin (21): It is a flavonone glycoside found majorly in Citrus paradisi Macfad. (Rutaceae). It was evaluated by Kandhare et al. for its neuroprotective effect in STZ induced male wistar rats. Dose dependent attenuation of nociceptive threshold, endogenous antioxidant and membrane bound inorganic phosphate enzyme and decrease in neural cell apoptosis were found with treatment of naringin (40 and 80 $\mathrm{mg} / \mathrm{kg} \mathrm{b.w/day} \mathrm{p.o.)} \mathrm{for} \mathrm{four} \mathrm{weeks} \mathrm{[66].}$

\section{Extracts}

Table 3 summarizes list of plants and their extracts reported to have protective effect in diabetic neuropathy.

\section{Miscellaneous}

Coffee: Hong et al. investigated the effect of coffee, trigonelline (22), and caffeine (23) on auditory neuropathy, a hearing disorder characterized by abnormal auditory brainstem response in which coffee $(35,100$, or $300 \mathrm{mg} / \mathrm{kg}$ b.w/day p.o.), trigonelline $(10 \mathrm{mg} / \mathrm{kg} \mathrm{b.w/day} \mathrm{p.o.)} \mathrm{or} \mathrm{caf-}$ feine $(10 \mathrm{mg} / \mathrm{kg}$ b.w/day p.o.) was administered to different groups of STZ induced male ICR mice. Amelioration in the hearing threshold shift and delayed latency of the auditory evoked potential was found [78].

Baimai-San prescription: A famous Chinese minority complex prescription used for curing neuropathy was administered at doses of $0.1,0.3$, and $0.9 \mathrm{mg} / \mathrm{kg} \mathrm{b.w} /$ day i.g. for 75 days to STZ induced male wistar rats by Liu et al. to evaluate its beneficial effects on peripheral neuropathy. Picroside II (24), ellagic acid (25), borneol (26), verbascose (27) and taurine (12) were found to be the effective compounds present in Baimai San through the use of high throughput screening. Reductions in the MNCV of sciatic nerve, sensory nerve conduction velocity and response speed to pain in the sciatic nerve fibre were determined. Increased neuronal survival rates, decreased LDH release, alleviation in the loss of neurite length through experiments from primary cortical neuronal cultures was found [79].

Nigella sativa oil and Thymoquinone (28): Nigella sativa L. (Ranunculaceae) and its active constituent Thymoquinone, a quinone derivative, were found by Hamdy et al. to attenuate oxidative stress in the heart and brain of STZ induced male wistar albino rats administered with $1 \mathrm{~mL} / \mathrm{kg}$ b.w/day p.o. of oil or $10 \mathrm{mg} / \mathrm{kg} \mathrm{b.w/day} \mathrm{p.o.} \mathrm{of} \mathrm{thymoqui-}$ none. Significant decrease in heart and brain NO and MDA concentrations, significant increase in Glutathione-Stransferase (GST), GSH and CAT, and restoration of Serum creatine kinase MB isoenzyme was found [80].

Evening primrose oil (EPO): It is the oil obtained from genus Oenothera (Onagraceae). It was administered (1.25 $\mathrm{g} / \mathrm{kg}$ b.w/day p.o.) for two weeks in STZ induced male rats. Reduction of the size of islets of Langerhans, fatty degeneration in the pancreatic acini with dilation, irregularity, increased thickness of blood vessels, and multiple vaculations, partial separation of myelinated nerve fibres with axonal atrophy, endoneural edema, and increased collagen fibres in sciatic nerves of diabetic rats, was found by Omran to be partially recovered by the treatment. Significant decrease in myelin breakdown and improvement in the ultra structural features of axons was aloso found [81].

\section{DIABETIC NEPHROPATHY}

Diabetic nephropathy, one of the major complications associated with diabetes involves renal failure, which is characterized by the development of renal hypertrophy, polyuria, hyperfiltration, microalbuminuria, abnormal changes in the renal tissue, reduction in basement membrane thickening and mesangial proliferation formation. If left untreated over a long period of time, it results in uremia, which is fatal. Once nephropathy is established, severe alterations with respect to blood pressure is observed which may lead to cardiovascular disease [4]. 
<smiles>Cc1coc2c1C(=O)C(=O)c1c-2ccc2c1CCCC2(C)C</smiles>

20<smiles>Cn1c(=O)c2c(ncn2C)n(C)c1=O</smiles>

23

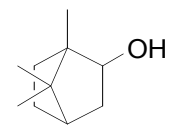

26

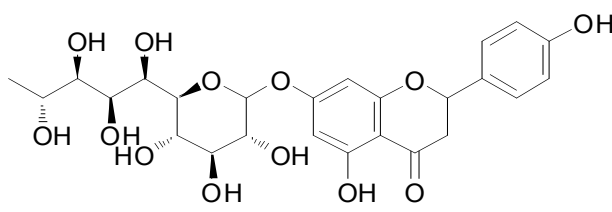

21

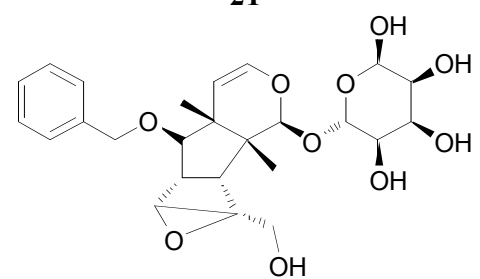

24<smiles>C[n+]1cccc(C(=O)[O-])c1</smiles>

22<smiles>O=c1oc2c(O)c(O)cc3c(=O)oc4c(O)c(O)cc1c4c23</smiles>

25

28

Fig. (3). Structures of phytochemicals (20-28) active against diabetic neuropathy.

Table 3. Plants and their extracts reported to have protective effect in diabetic neuropathy.

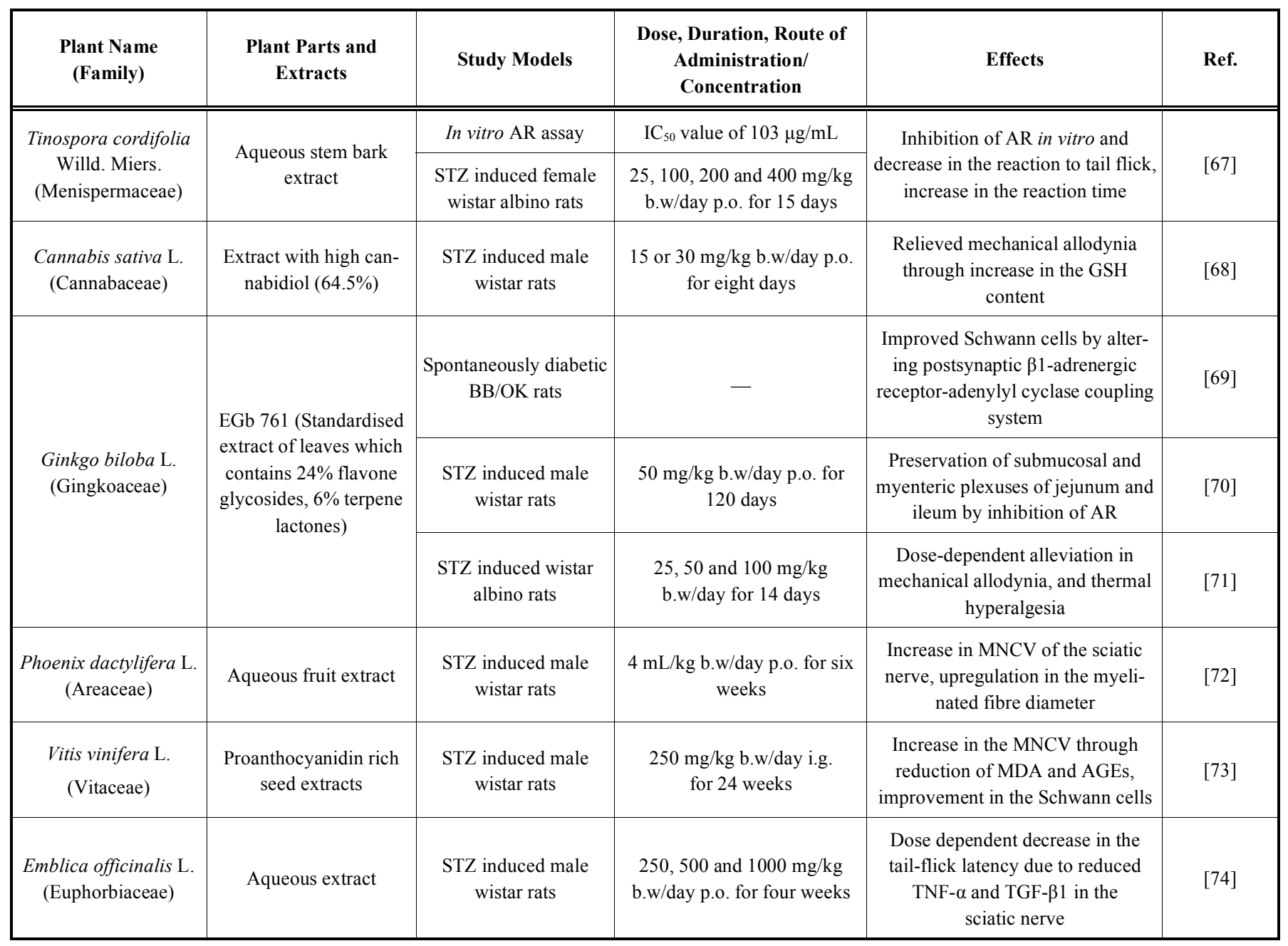


(Table 3) contd....

\begin{tabular}{|c|c|c|c|c|}
\hline $\begin{array}{c}\text { Plant Name } \\
\text { (Family) }\end{array}$ & $\begin{array}{c}\text { Plant Parts and } \\
\text { Extracts }\end{array}$ & Study Models & $\begin{array}{c}\text { Dose, Duration, Route of } \\
\text { Administration/ } \\
\text { Concentration }\end{array}$ & Effects \\
\hline \hline $\begin{array}{c}\text { Artemisia dracunculus } \\
\text { L. (Asteraceae) }\end{array}$ & $\begin{array}{c}\text { PMI-5011 (standard } \\
\text { ethanolic extract) }\end{array}$ & $\begin{array}{c}\text { STZ induced } \\
\text { C57BL6/J mice }\end{array}$ & $\begin{array}{c}500 \mathrm{mg} / \mathrm{kg} \text { b.w/day for seven } \\
\text { weeks }\end{array}$ & $\begin{array}{c}\text { Alleviation in MNCV, tactile } \\
\text { allodynia through activation of } \\
\text { spinal cord 12/15-lipoxygenase }\end{array}$ \\
\hline $\begin{array}{c}\text { Hygrophila spinosa } \mathrm{T} . \\
\text { Anders. (Acanthaceae) }\end{array}$ & $\begin{array}{c}\text { Methanolic extract of } \\
\text { aerial parts }\end{array}$ & $\begin{array}{c}\text { Alloxan induced wistar } \\
\text { rats of either sex }\end{array}$ & $\begin{array}{c}250,500 \text { and } 750 \mathrm{mg} / \mathrm{kg} \\
\text { b.w/day for six weeks }\end{array}$ & $\begin{array}{c}\text { Increase in the pain threshold } \\
\text { levels through restoration of LPO } \\
\text { and antioxidant enzyme levels of } \\
\text { sciatic nerve }\end{array}$ \\
\hline $\begin{array}{c}\text { Terminalia arjuna } \\
\text { Wight \& Arn. } \\
\text { (Combretaceae) }\end{array}$ & $\begin{array}{c}50 \% \text { aqueous ethanol } \\
\text { extract }\end{array}$ & $\begin{array}{c}\text { STZ induced male } \\
\text { wistar albino rats }\end{array}$ & $\begin{array}{c}500 \mathrm{mg} / \mathrm{kg} \text { b.w/day p.o. for } \\
30 \text { days }\end{array}$ & $\begin{array}{c}\text { Alleviation in impairment of the } \\
\text { reflex bradycardia through reduc- } \\
\text { tion in inflammatory cytokines }\end{array}$ \\
{$[777]$} \\
\hline
\end{tabular}

\section{Pure Compounds}

Various purified natural products have been tested in different in vitro and in vivo models for their potential in treatment of diabetic nephropathy (See Fig. 4) and are described below.

Andrographolide (29) and 14-deoxy-11,12didehydroandrographolide (30): These compounds belonging to the class of diterpene lactones, isolated from Andrographis paniculata Nees. (Acanthaceae) Lee et al. investigated its effects on murine renal mesangial cell line (MES)13, an SV40 transformed murine glomerular mesangial cell line, cultured in high concentration of glucose. Reduction in nephropathic phenotypes, reduction of apoptosis marker caspase-3, fibrosis marker TGF- $\beta 1$, and Plasminogen activator inhibitor-1 (PAI-1) was found at concentrations of 10 and $1 \mu \mathrm{M}$ respectively. Regulation of intracellular signaling transduction along with clearance of ROS was suggested to be the mechanism behind the effect [82].

Taurine (12): Taurine was evaluated by Huang et al. for its inhibition of AGE-induced hypertrophy in renal tubular epithelial cells. It was found that the AGE-induced Raf-1/ ERK activation was markedly blocked by taurine (10-1000 $\mu \mathrm{M})$ through which a significant decrease in cell size, cellular hypertrophy index, and protein levels of RAGE, Cyclindependent kinase inhibitor $1 \mathrm{~B}\left(\mathrm{p} 27^{\mathrm{Kip} 1}\right)$, collagen IV and FN was found suggesting its anti-fibrotic activity [83].

Curcumin (31) and demethoxycurcumin (32): These compounds belong to the class of Diarylheptanoids obtained from Curcuma longa L. (Zingiberaceae). They were evaluated by Liu et al. for their activities on AGEs-induced oxidative stress and apoptosis, associated with the damage to mesangial cells. Significant restoration of AGEs-induced apoptosis to normal levels with $\mathrm{IC}_{50}$ values of $3.874 \times 10^{-11} \mathrm{M}$ and $6.085 \times 10^{-11} \mathrm{M}$ respectively, reduction of ROS generation in mesangial cells, elevation in AGEs-decreased SOD activity and decrease in AGEs-increased MDA content in cell culture supernatant was found in vitro in rat mesangial cell line HBZY-1 [84].

Rhein (33): It is an anthraquinone obtained from Rheum species (Polygonaceae). Yu et al. investigated the effets of rhein on high glucose and Ang II induced renal proximal tubular epithelial cells obtained from anesthetized SD rats by microdissection. Decrease in cell size, 3H-leucine incorporation and cellular protein content was found with 5, 15, and $30 \mathrm{mg} / \mathrm{L}$ concentrations of Rhein after $72 \mathrm{hrs}$ [85].

7-O-galloyl-D-sedoheptulose (34): It is a phenolic compound isolated from Cornus officinalis Torr. ex. Dur. (Cornaceae). Park et al. investigated its effects by administering 20 and $100 \mathrm{mg} / \mathrm{kg} \mathrm{b.w/day} \mathrm{p.o.} \mathrm{for} \mathrm{six} \mathrm{weeks} \mathrm{to} \mathrm{C57BLKS/J}$ $\mathrm{db} / \mathrm{db}$ mice. Attenuation of renal oxidative stress through reduction of ROS and lipid peroxidation, increase in the ratio of $\mathrm{GSH} / \mathrm{GSSG}$, reduction in renal protein expression of NADPH oxidase 4 (Nox 4) and p22 (phox), pro-apoptotic factors (such as Bax and cytochrome c) and NF-kB targeting pro-inflammatory iNOS and COX-2 was found [86]. The renoprotective effect of the compound was also investigated by Yamabe et al. on STZ induced male wistar rats administered with 20 or $100 \mathrm{mg} / \mathrm{kg}$ b.w/day p.o. for 20 days. Modulation in the levels of TBARS in serum, and methylglyoxal and glycolaldehyde levels in kidney was found [87].

Caffeic acid (35) and ellagic acid (25): These compounds belong to the classes of hydroxycinnamic acid and natural phenol antioxidant respectively, Chao et al. assessed the nephropreotective effects of these acids where they were mixed in the diet at 2.5 and $5 \%$ concentrations and supplied to male Balb/cA mice for 12 weeks. Dose dependent reduction in plasma blood urea nitrogen (BUN), elevation in creatinine clearance and significant decrease in the levels of plasma glycated hemoglobin (HbA1c), urinary glycated albumin, renal carboxymethyllysine, pentosidine, sorbitol and fructose was found. Renal activity of AR and sorbitol dehydrogenase was diminished and the mRNA expression of renal AR was suppressed. Renal levels of IL- 6 , IL- $1 \beta$, TNF- $\alpha$ and MCP-1 was lowered. Dose dependent down-regulation of TNF- $\alpha$ and MCP-1 mRNA expression in kidney was also found [88].

Genistein (16): It is an isoflavone, majorly found in Glycine $\max$ L. (Fabaceae). It was investigated by Palanisamy et al. that genistein preserved renal ultrastructural integrity and down regulated $\mathrm{BP}$ to normal by restoring $\mathrm{ACE}, \mathrm{PKC}-\beta \mathrm{II}$ and eNOS in fructose fed hypertensive male wistar rats administered with $1 \mathrm{mg} / \mathrm{kg}$ b.w/day of genistein [37].

2-Dodecyl-6-methoxycyclohexa-2,5-dien-1,4-dione (36): It is a benzoquinone derivative isolated from the tuberous 
<smiles>C=C1CC[C@]2(C(C)O)[C@H](C)C(=O)OC[C@@H]2CC[C@H]1C/C=C1/C(=O)OC[C@H]1O</smiles>

29<smiles>COc1cc(/C=C/C(=O)CC(=O)/C=C/c2ccc(O)cc2)ccc1O</smiles>

32<smiles>O=C(O)/C=C/c1ccc(O)c(O)c1</smiles>

35<smiles>Oc1cc(O)c2c(c1)OC(c1ccc(O)c(O)c1)C(O)C2</smiles>

38

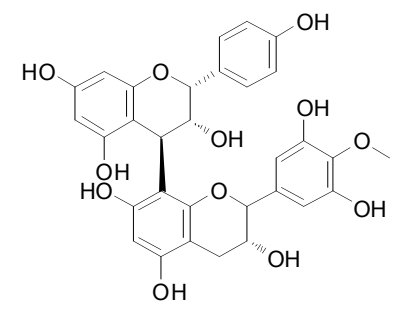

41

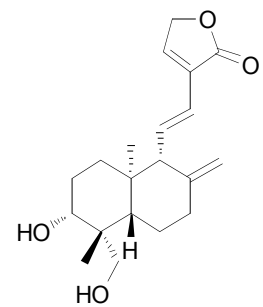

30

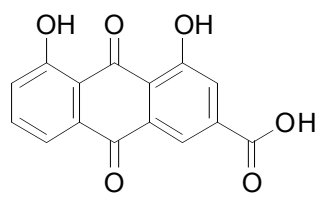

33

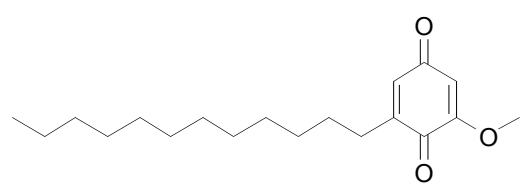

36

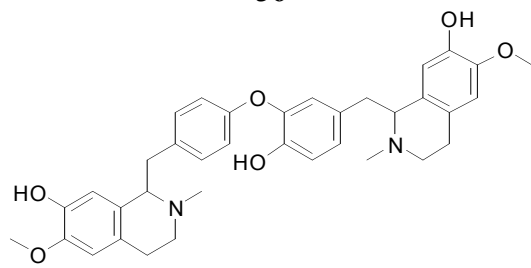

39

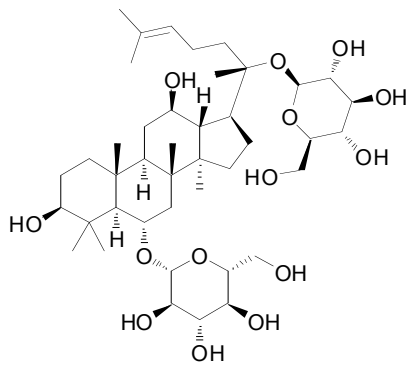

42

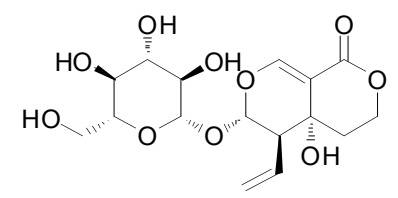

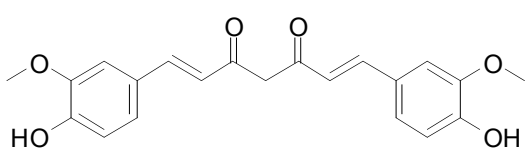

31<smiles>O=C(OCC(O)[C@H](O)[C@H](O)[C@H](O)C(=O)CO)c1cc(O)c(O)c(O)c1</smiles>

34

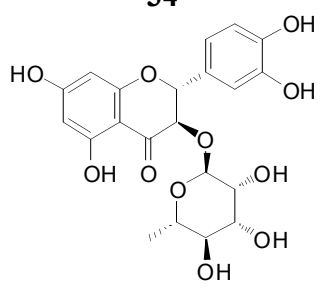

37

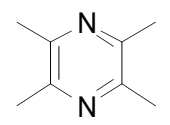

40<smiles>COc1cc(O[C@H]2O[C@H](CO[C@H]3O[C@H](CO)[C@@H](O)[C@H](O)[C@H]3O)[C@@H](O)[C@H](O)[C@H]2O)c2c(O)c3c(=O)cc(C)oc3cc2c1</smiles>

43

44

Fig. (4). Structures of phytochemicals (29-44) active against diabetic nephropathy.

roots of Averrhoa carambola L. (Oxalidaceae). Zheng et al. investigated its effects where the compound was administered to KKAy diabetic mice at doses of 12.5, 25, and 50 $\mathrm{mg} / \mathrm{kg} \mathrm{b.w./day} \mathrm{for} \mathrm{eight} \mathrm{weeks.} \mathrm{Decrease} \mathrm{in} \mathrm{hyperglycemia,}$ renal AGE formation, and the expression of related proteins, such as the AGE receptor, NF- $\kappa \mathrm{B}, \mathrm{TGF}-\beta 1$, and $\mathrm{N}(\varepsilon)$ (carboxymethyl)lysine, attenuation of glomerular mesangial matrix expansion and upregulation of SOD and GSH peroxidase were found with the treatment [89].
Astilbin (37): It is a flavonoid compound, isolated from the rhizomes of Smilax glabra Roxb. (Smilacaceae). It was studied by Li et al. in vitro and in vivo using high glucose stimulated proximal tubule epithelial cell line (HK-2) and STZ induced male SD rats. Inhibition of TGF- $\beta 1$ and CTGF in vitro at concentrations from 0.3 to $3 \mu \mathrm{M}$, and significant amelioration in renal functions and reduction in kidney index in vivo with 2.5 or $5 \mathrm{mg} / \mathrm{kg}$ b.w/day i.g of astilbin in a 12 week study was found [90]. 
(+)-Catechin (38): It is one of the major polyphenols of Camellia sinensis (L.). Kuntze. (Theaceae). Administration of catechin to STZ induced male SD rats at a concentration of $35 \mathrm{mg} / \mathrm{dL} /$ day in drinking water for 12 weeks was found by Chennasamudram et al. to lower the levels of ET-1, LPO, concentration of alanine transferase enzyme, and expression of FN and suggested that the co-administration of catechin and enalapril might be useful in reducing albumin excretion as well as improving endothelial function for clinical situations where ACE inhibitors are poorly tolerated [91].

Magnoline (39): It is an active constituent isolated from Magnolia fargesii Cheng. (Magnoliaceae). It was found to attenuate the levels of P-selectin and TGF- $\beta 1$ by Zhou et al. in STZ induced male SD rats administered with 0.5 and 2 $\mathrm{mg} / \mathrm{kg} \mathrm{b.w/day} \mathrm{i.v.} \mathrm{for} 16$ weeks [92].

Icariin (15): Qi et al. found that the compound reduced elevated MDA and Hydroxyproline levels and upregulated decreased SOD in renal tissues of STZ induced male SD rats at dose of $80 \mathrm{mg} / \mathrm{kg} \mathrm{b.w} /$ day i.g. for a period of seven weeks [93].

Tetramethylpyrazine (40): It is also known as Ligustrazine. It is an alkaloid obtained from genus Ligusticum (Apiaceae). Yang et al. investigated the nephroprotective effects of tetramethylpyrazine where the compound was administered to STZ induced male SD rats at a dose of 200 $\mathrm{mg} / \mathrm{kg} \mathrm{b.w/day} \mathrm{i.g} \mathrm{for} \mathrm{eight} \mathrm{weeks.} \mathrm{Decrease} \mathrm{in} \mathrm{the} \mathrm{expres-}$ sion of VEGF was found [94].

Oleanolic acid (14): Mapanga et al. isolated oleanolic acid from the leaves of Syzygium cordatum Hochst. (Myrtaceae), and evaluated its nephroprotective effects in STZ induced male SD rats by administering $60 \mathrm{mg} / \mathrm{kg}$ b.w/day p.o. of oleanolic acid for five weeks. Significant increase in $\mathrm{Na}^{+}$ excretion rates without affecting urine flow, $\mathrm{K}^{+}$and $\mathrm{Cl}^{-}$rates, and increased creatinine clearance with concomitant reduction of plasma creatinine concentration and decreased mean arterial BP was found [95].

Procyanidin B2 (41): It is a B type proanthocyanidin majorly found in Vitis vinifera L. (Vitaceae). It was investigated by Zhang et al. for its nephroprotective effects through proteomic analysis of kidneys of male C57BLKS/J db/db mice treated with $30 \mathrm{mg} / \mathrm{kg} \mathrm{b}$.w/day p.o. for 10 weeks. It was found that it down-regulated milk fat globule-Epidermal growth factor 8, along with ERK1/2 and Glycogen synthase kinase-3 $\beta$ signaling pathways [96].

Ginsenoside Rg1 (42): It is a steroid glycoside obtained from Panax quinquefolius L. (Araliaceae). It was evaluated by Ma et al. on STZ induced diabetic nephropathic rats. Reduction in TGF- $\beta 1$ expression and the levels of serum creatinine, cross reaction protein, TNF- $\alpha$, ectodermal dysplasia-1 in the renal tissues were found [97].

\section{Extracts}

Table 4 summarizes list of plants and their extracts reported to have protective effect in diabetic nephropathy as investigated through various cell culture, in vitro and in vivo studies.

\section{Miscellaneous}

Tangnaikang: The effect of Tangnaikang (TNK) on renal interstitial fibrosis was studied by Yang et al. in vitro through transdifferentiation of the human renal tubular epithelial cell line HK-2 induced by TGF- $\beta 1$. Three groups each containing $10 \mathrm{ng} / \mathrm{mL}$ of TGF- $\beta 1$, and $5 \%, 10 \%$ and $20 \%$ TNK serum was investigated for cell proliferation, expression of $\alpha$-SMA, E-cadherin and contents of collagen I, collagen III, and FN. Decrease in the expression of $\alpha$-SMA, increased expression of E-cadherin and inhibition of cell proliferation and the secretion of collagen I, collagen III and FN was found [129].

Huangkui capsule: It is a TCM preparation containing total flavones of Abelmoschus manihot L. (Malvaceae) as major components. It was investigated by Omara et al. for its effectiveness in chronic kidney disease. Improvement in immunological reaction, inflammation, renal fibrosis, and renal tubular epithelial injury was found in male SD rats administered with $0.75 \mathrm{~g} / \mathrm{kg} \mathrm{b.w} /$ day p.o. for ten days [130].

Enicostemma littorale and swertiamarin (44): In a study conducted by Lee et al., the aqueous extract of Eincostemma littorale Blume. (Gentianaceae) and swertiamarin, an iridoid glucoside were administered to STZ induced male SD rats at a dose of $1 \mathrm{~g} / \mathrm{kg} \mathrm{b.w/day} \mathrm{and} 50 \mathrm{mg} / \mathrm{kg} \mathrm{b.w/day} \mathrm{p.o.} \mathrm{respec-}$ tively for three weeks. Significant decrease in serum urea and creatinine, and improvement in histology of glomerular function was found [131].

Tocotrienol rich fraction (TRF) from palm oil and rice bran oil: Two fractions of the tocotrienol rich extracts, one each from palm oil and rice bran oil were administered to STZ induced male wistar rats at a dose of $200 \mathrm{mg} / \mathrm{kg}$ b.w/day p.o. for eight weeks. Zhang et al. found an improvement in renal function through reduction of oxidative stress in both the cases with palm oil fraction being more efficient as compared to the fraction of rice bran oil [132].

Croatian propolis: The effect of Row Croatian propolis was studied by Orsolic et al. by administering $(50 \mathrm{mg} / \mathrm{kg}$ b.w/day i.p.) of the water soluble and ethanolic extracts for seven days in alloxan induced Swiss albino mice. Decrease in number of vacuolized cells and degree of vacuolization, improvement in impairment of fatty acid metabolism was found but no alleviation was exhibited in renal histology. Attenuation in diabetic hepatorenal damage through its antioxidative action and detoxification was also found [133].

Schisandrae chinensis, Rhizoma chuanxiong, Cocha ostreae: Zhang et al. studied the ethanol extracts of these preparations from TCM by administration to STZ induced male C57BL/6 mice at a dose of $5 \mathrm{~g} / \mathrm{kg}$ b.w/day p.o for nine weeks. The expressions of FN, $\alpha$-SMA and PAI-1 were decreased along inhibition of the epithelial to mesenchymal transdifferentiation, endothelial myofibroblast transition and PAI-1 expression [134].

\section{NATURAL PRODUCTS IN CLINICAL STUDIES AGAINST DIABETIC COMPLICATIONS}

Apart from the different in vitro, cell culture and in vivo studies of different natural products on various diabetic complications, one pure phytochemical, 11 plant extracts and 11 herbal formulations have also been investigated in clinical studies for their protective effects on different diabetic complications which are summarized in Table 5. 
Table 4. Plants and their extracts reported to have protective effect in diabetic nephropathy.

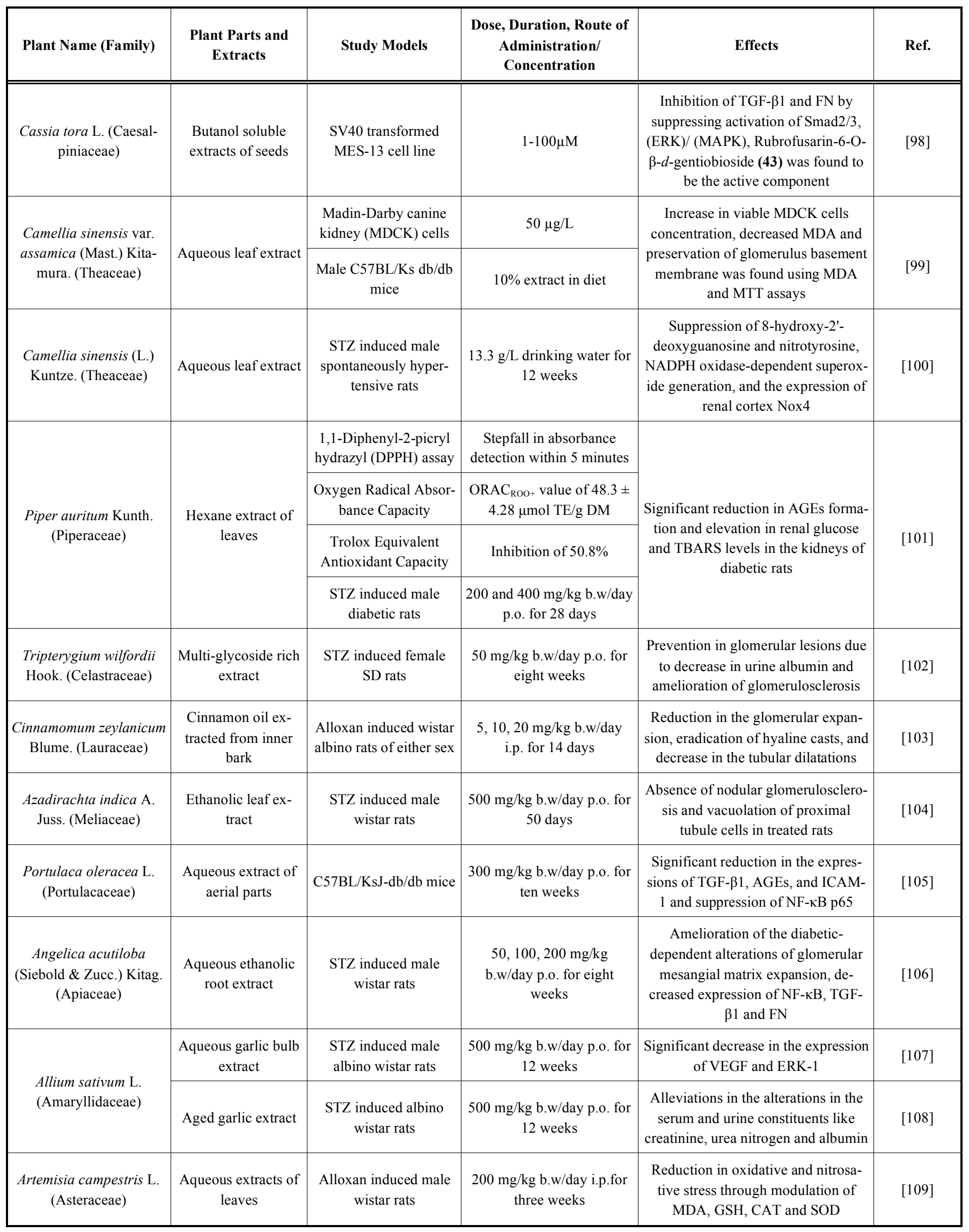


(Table 4) contd....

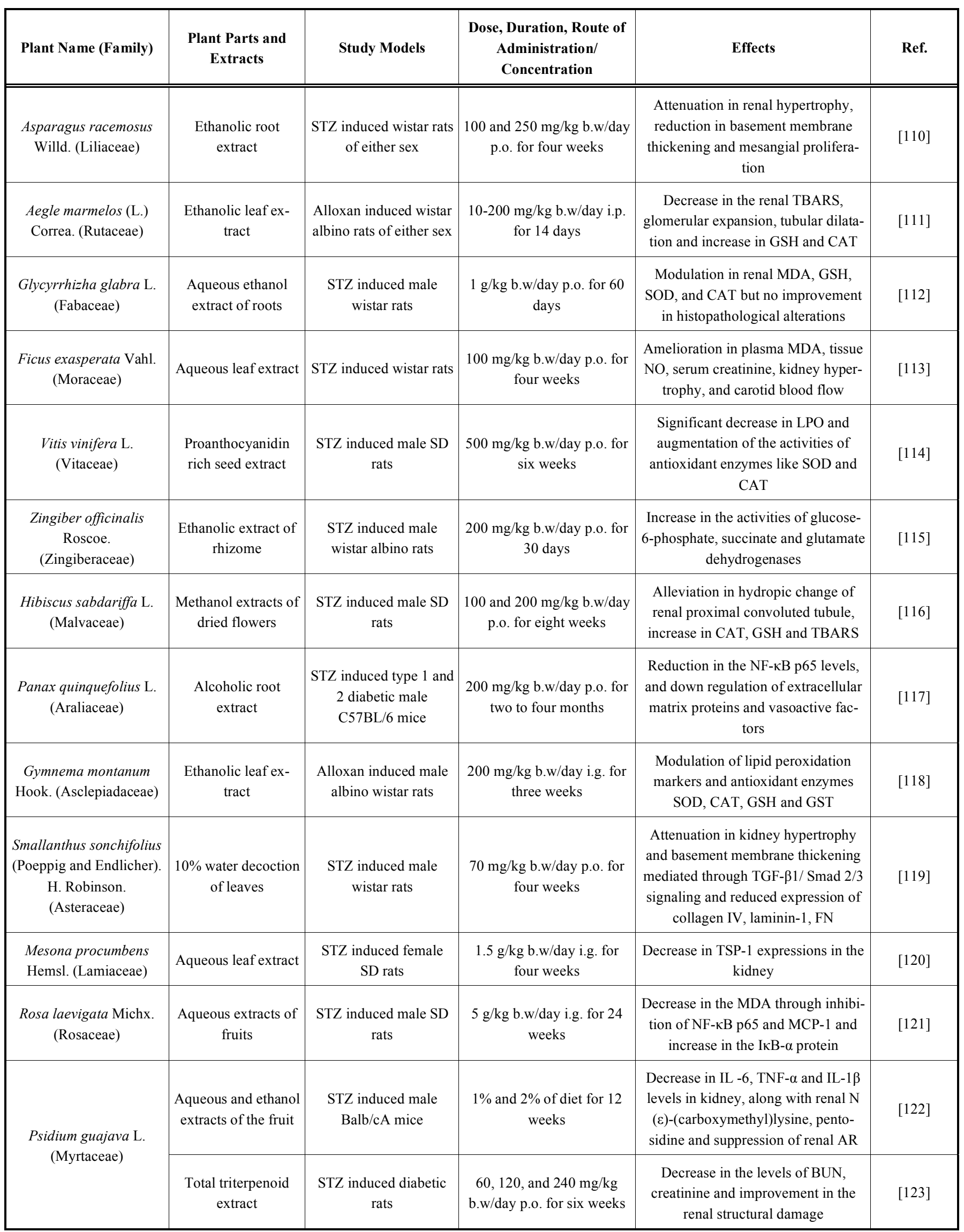


(Table 4) contd....

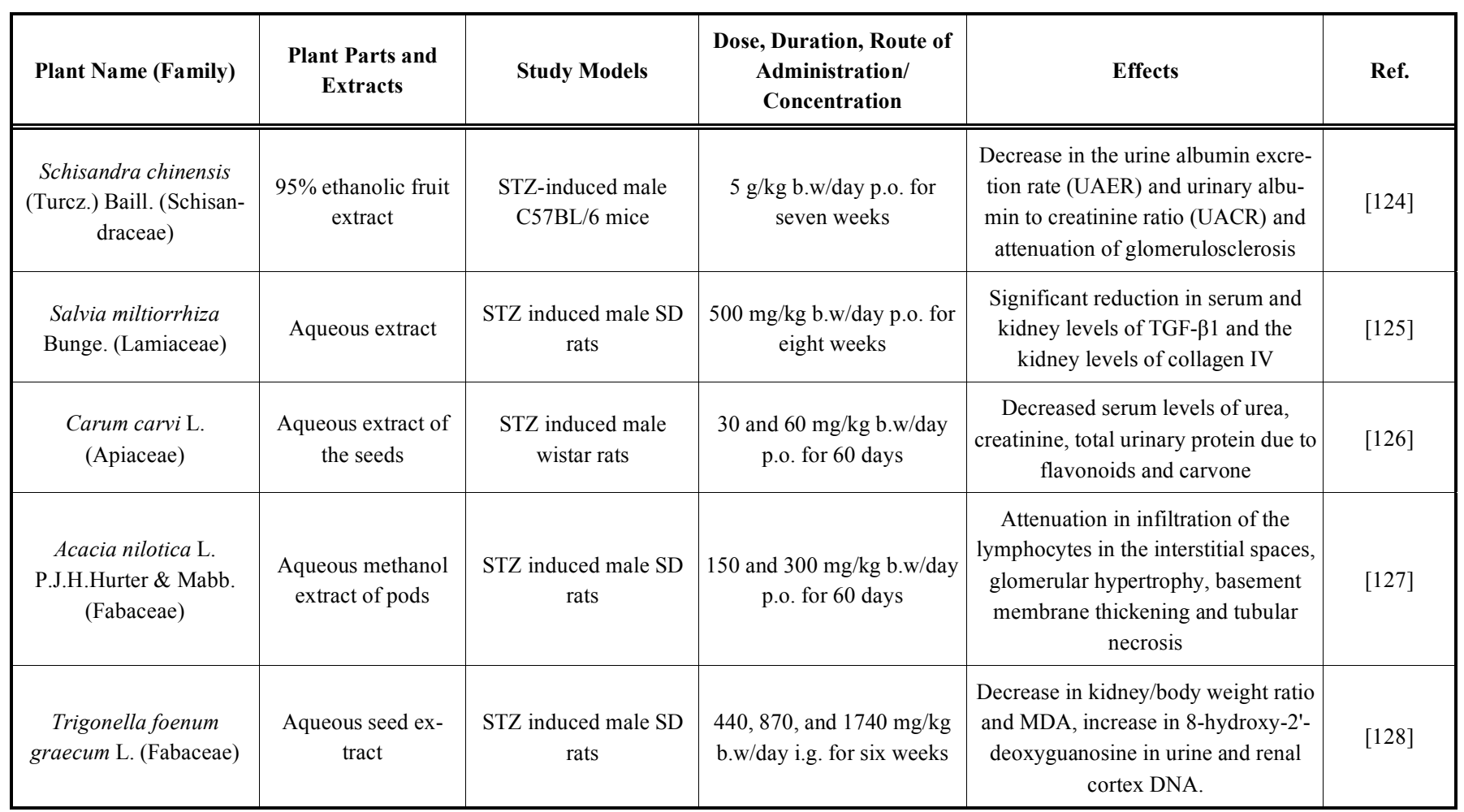

Table 5. Summary of different formulations, Plant extracts and pure phytochemicals investigated in clinical studies for their effects in diabetic complications.

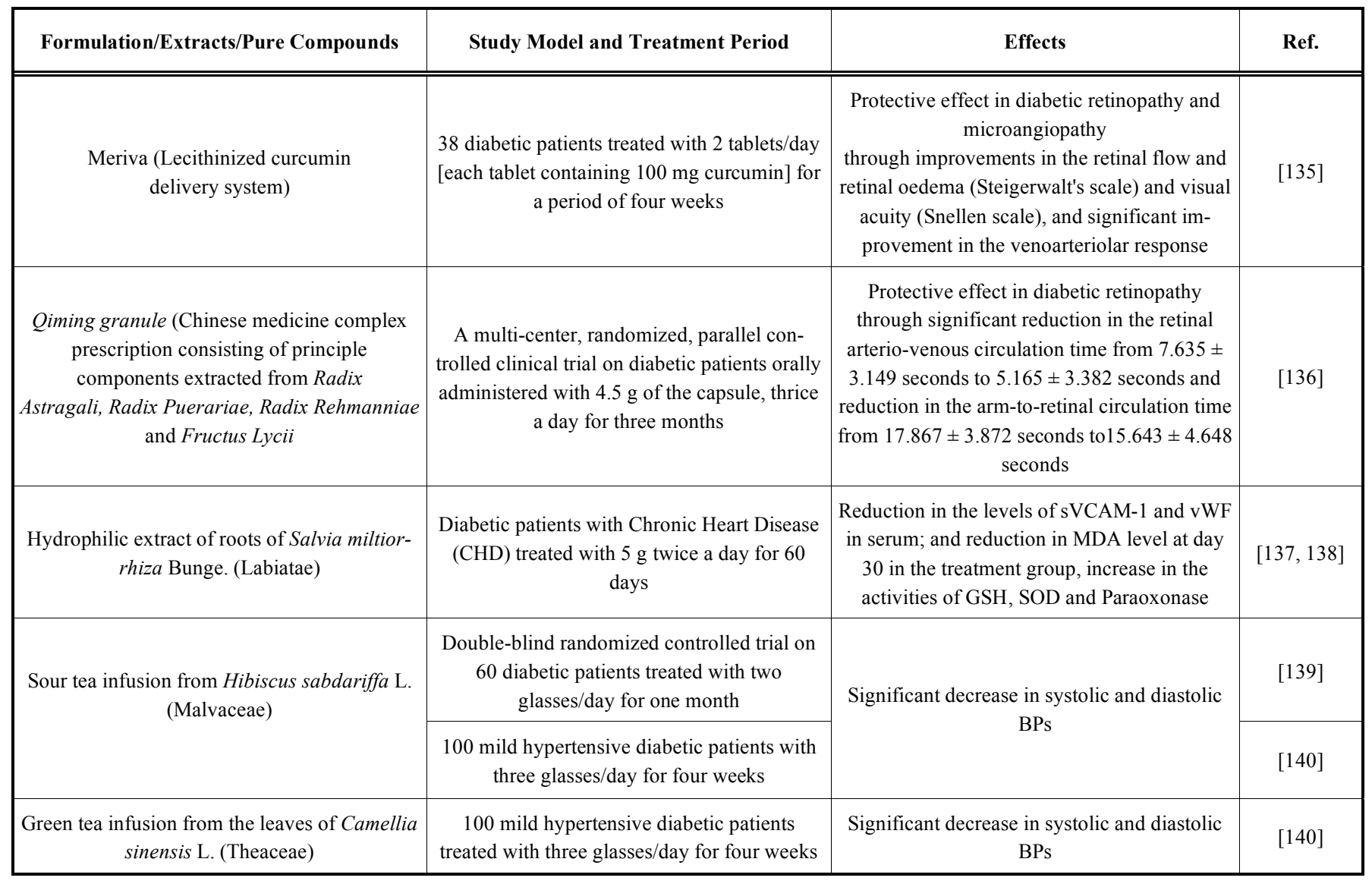


(Table 5) contd....

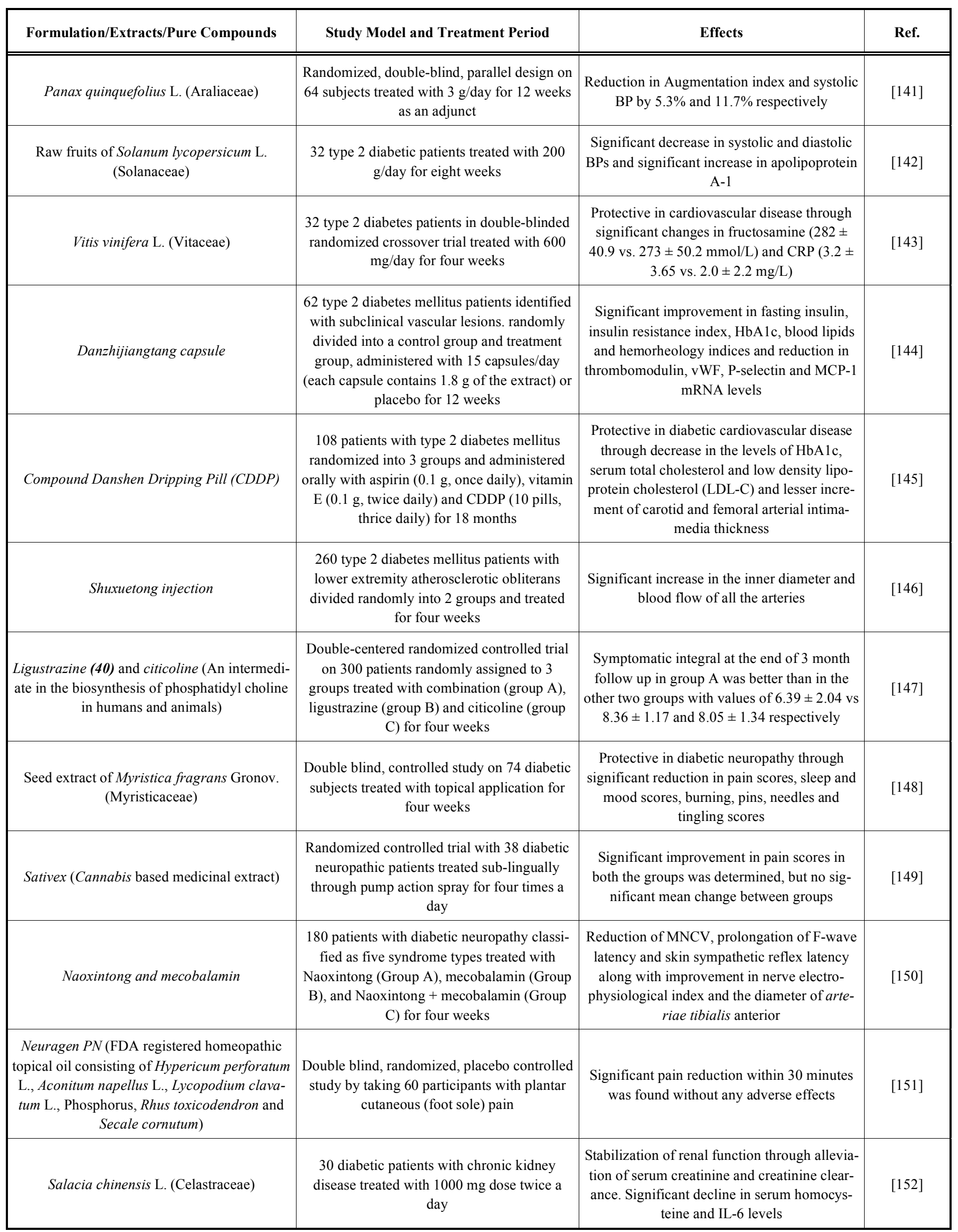


(Table 5) contd....

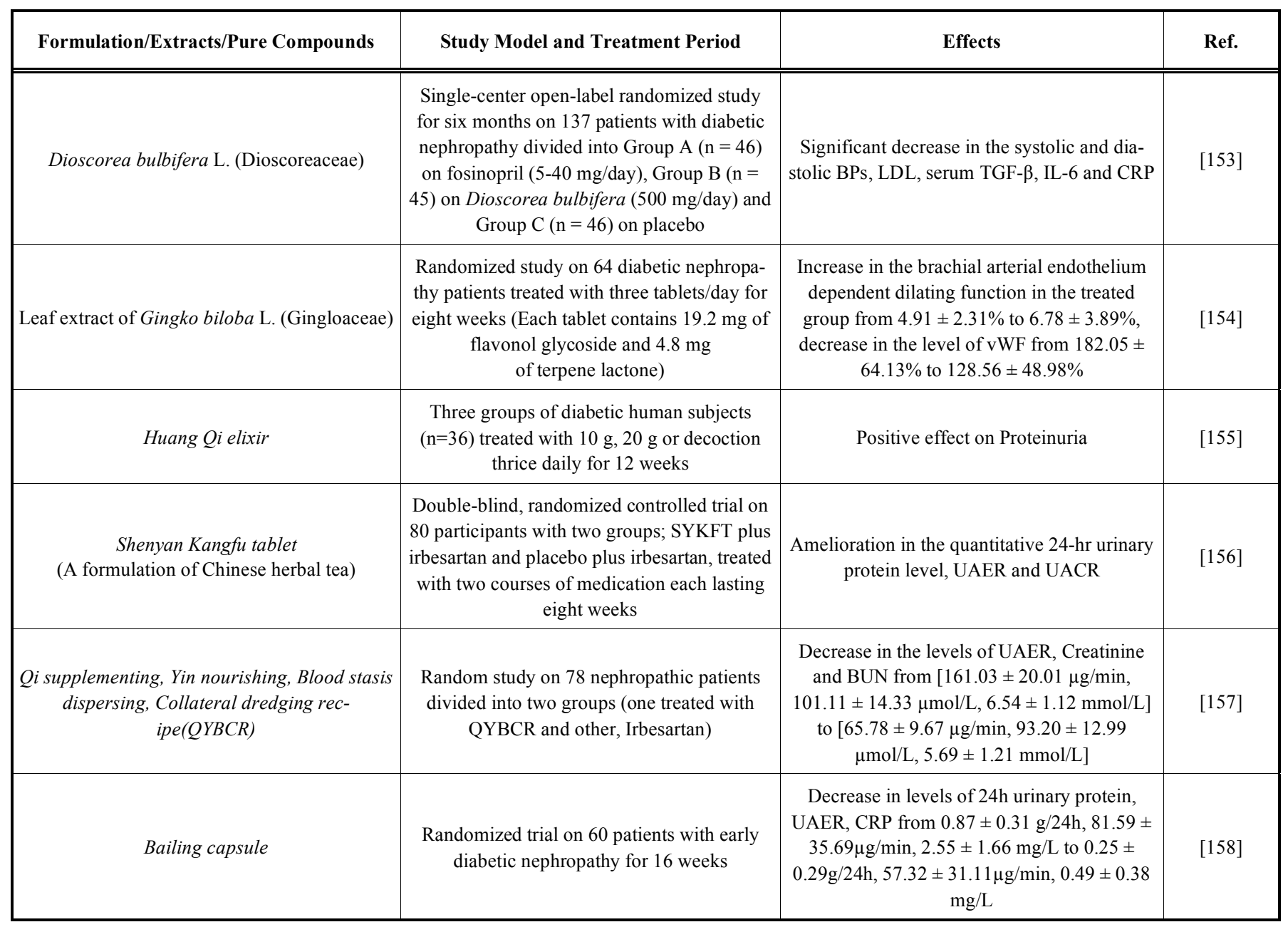

\section{CONCLUSION}

In this review, recent discoveries on utilization of natural products for treatment of diabetic complications from 20082014 have been discussed with 158 references which include in vitro, cell culture, in vivo and clinical studies. In total 44 pure phytochemicals, 61 plants and around 20 traditional medicinal formulations have been explored for their potential against diabetic complications. Extracts of three plants namely Salvia miltiorrhiza, Panax quinquefolius, and Vitis vinifera were found to be effective in treating diabetic nephropathy, cardiomyopathy and retinopathy, respectively. EGCG was the only compound reported to be effective in three diabetic complications (retinopathy, cardiomyopathy and neuropathy). Thus it proves the potential of natural products in treatment of diabetic complications. However there is an urgent need to further investigate EGCG for its potential to develop it into clinical drug against diabetic complications. Also there is need for isolation and characterization of the active extracts to identify the bioactive phytochemicals. Such phytochemicals may act as possible leads to develop new drugs that may be used singly or in combination therapy for treating diabetic complications.

Natural products have been widely used for the treatment of diabetes and its complications in folk medicine/traditional system of medicines. However the major hurdle in populari- zation and commercialization of this class of therapeutics has been often ascribed to geographical and seasonal variations. Another reason for decline in popularizations of natural products has been the scarcity of authoritative clinical data related to the effectiveness in improving diabetic complications. At times the observed clinical activity has also been ascribed to group of phytochemicals displaying synergy. Hence it is important to answer these questions to popularize this therapeutics. Defined clinical studies coupled with state of art analytical experiments for assuring the quality product are the need of the hr. With high public interest in usage of natural product based therapeutics for diabetes and related complications it is important to explore the potential of this therapeutics. Thus the present review highlights the potential of natural products for treatment of diabetic complications and also urges the natural product and analytical chemists to solve the enigma of natural products with the help of modern technology.
ABBREVIATIONS
$\alpha$-SMA $=\alpha$-Smooth muscle actin
$\mathrm{ACE} \quad=$ Angiotensin converting enzyme
AGEs $=$ Advanced Glycation End products
$\mathrm{AR}=$ Aldose reductase 


$\begin{array}{llll}\text { ARPE-19 } & =\text { Arising retinal pigment epithelial } & \text { TRF } & =\text { Tocotrienol rich fraction } \\ \mathrm{BP} & =\text { Blood pressure } & \mathrm{TSP} & =\text { Thrombospondin } \\ \mathrm{BUN} & \mathrm{TXB} & =\text { Thromboxane } \mathrm{B}_{2} \\ \mathrm{CAT} & =\text { Catalase } & \mathrm{UACR} & =\text { Urinary albumin to creatinine ratio } \\ \mathrm{COX}-2 & =\text { Cyclooxygenase-2 } & \mathrm{UAER} & =\text { Urine albumin excretion rate } \\ \mathrm{CRP} & =\text { C-reactive protein } & \text { vCAM } & =\text { Vascular cell adhesion molecule } \\ \text { EGCG } & =\text { Epigallocatechin-3-gallate } & \text { VEGF } & =\text { Vascular Endothelial Growth Factor } \\ \text { eNOS } & =\text { Endothelial nitric oxide synthase } & \text { VSMC } & =\text { Vascular smooth muscle cells } \\ \text { EPO } & =\text { Evening primrose oil } & \text { vWF } & =\text { Von Willebrand factor }\end{array}$

ERK $=$ Extracellular signal-regulated kinase

$\mathrm{FN}=$ Fibronectin

FOXO $=$ Forkhead box $\mathrm{O}$

$\mathrm{GSH}=$ Reduced glutathione

GSSG = Oxidized glutathione

GST = Glutathione-S-transferase

$\mathrm{HbA} 1 \mathrm{c}=$ Hemoglobin A1c

HK-2 = Proximal tubule epithelial cell line

ICAM = Intercellular adhesion molecule

iNOS = Inducible nitric oxide synthase

JNK $=$ c-Jun-N-terminal kinase

ILs $=$ Interleukins

LADA $=$ Latent Autoimmune Diabetes in Adults

LPO $=$ Lipid peroxide

MAPK $=$ Mitogen activated protein kinase

MDA $=$ Malondialdehyde

$\mathrm{MNCV}=$ Motor nerve conducting velocity

$\mathrm{NF}-\mathrm{kB}=$ Nuclear factor kappa $\mathrm{B}$

Nox-4 $=$ NADPH oxidase 4

SOD $=$ Superoxide dismutase

PAI-1 = Plasminogen activator inhibitor-1

$\mathrm{PKC}=$ Protein kinase $\mathrm{C}$

$\operatorname{PPAR} \gamma=$ Peroxisome proliferator activated receptor

RLAR $=$ Rat lens aldose reductase

$\mathrm{SD}=$ Sprague-Dawley

SGLT $=$ Sodium-glucose symporters

SGLT1 = Sodium-glucose co-transporter 1

SGLT2 = Sodium-glucose co-transporter 2

$\mathrm{STZ}=$ Streptozotocin

TBARS $=$ Thiobarbituri acid reactive substances

$\mathrm{TCM}=$ Traditional Chinese Medicine

TGF $=$ Transforming growth factor

TNF $=$ Tumour necrosis factor

$\mathrm{TRB}=$ Tribbles homolog

\section{CONFLICT OF INTEREST}

The authors confirm that this article content has no conflict of interest.

\section{ACKNOWLEDGEMENTS}

Declared none.

\section{PATIENT'S CONSENT}

Declared none.

\section{REFERENCES}

[1] WHO | Diabetes. Available at: http://www.who.int/topics/diabetes mellitus/en/[Accessed January 16, 2014)]

[2] Diabetes Atlas International Diabetes Federation. Available at: http://www.idf.org/diabetesatlas [Accessed January 16, 2014].

[3] Morbidity and Mortality | International Diabetes Federation. Available at: http://www.idf.org/diabetesatlas/diabetes-mortality [Accessed January 16, 2014].

[4] Forbes, J.M.; Cooper, M.E. Mechanisms of diabetic complications. Physiol. Rev., 2013, 93 (1), 137-188.

[5] National Eye Institute | Facts about Diabetic Retinopathy. Available at: http://www.nei.nih.gov/health/diabetic/retinopathy.asp [Accessed on January 16, 2014].

[6] Frank, R.N. Diabetic retinopathy. N. Engl. J. Med., 2004, 350 (1), 48-58.

[7] Ye, P.; Lin, K.; Li, Z.; Liu, J.; Yao, K.; Xu, W. (-)-Epigallocatechin gallate regulates expression of apoptotic genes and protects cultured human lens epithelial cells under hyperglycemia. Mol. Biol., 2013, 47 (2), 251-257.

[8] Hao, M.; Kuang, H.Y.; Fu, Z.; Gao, X.Y.; Li, Y.; Chen, P.; Wang, $Y$. Protective effects of astragaloside IV on high-glucose-induced damage of retinal ganglion cells. Zhonghua. Yi. Xue. Za. Zhi., 2012, 92 (30), 2104-2107.

[9] Losso, J.N.; Truax, R.E.; Richard, G. Trans-resveratrol inhibits hyperglycemia-induced inflammation and connexin downregulation in retinal pigment epithelial cells. J. Agric. Food. Chem., 2010, 58 (14), 8246-8252.

[10] Srivastava, R.K.; Unterman, T.G.; Shankar, S. FOXO transcription factors and VEGF neutralizing antibody enhance antiangiogenic effects of resveratrol. Mol. Cell. Biochem., 2010, 337(1-2), 201-212.

[11] Park, S.H. Ginsenosides Rb2 protects high glucose-induced apoptosis in ARPE cells. Lab. Anim. Res., 2008, 24(1), 119-123.

[12] Jang, D.S.; Yoo, N.H.; Kim, N.H.; Lee, Y.M.; Kim, C.S.; Kim, J ; Kim, J.H.; Kim, J.S. 3,5-di-O-caffeoyl-epi-quinic acid from the leaves and stems of Erigeron annuus inhibits protein glycation, aldose reductase, and cataractogenesis. Biol. Pharm. Bull., 2010, 33 (2), 329-333.

[13] Kim, N.H.; Kim, Y.S.; Lee, Y.M.; Jang, D.S.; Kim, J.S. Inhibition of aldose reductase and xylose-induced lens opacity by puerariafuran from the roots of Pueraria lobata. Biol. Pharm. Bull., 2010, 33(9), 1605-1609.

[14] Lee, J.; Kim, N.H.; Nam, J.W.; Lee, Y.M.; Jang, D.S.; Kim, Y.S.; Nam, S.H.; Seo, E.K.; Yang, M.S.; Kim, J.S. Scopoletin from the 
flower buds of Magnolia fargesii inhibits protein glycation, aldose reductase, and cataractogenesis ex vivo. Arch. Pharm Res., 2010, 33(9), 1317-1323.

[15] Puppala, M.; Ponder, J.; Suryanarayana, P.; Reddy, G.B.; Petrash, J.M.; LaBarbera, D.V. The isolation and characterization of $\beta$ glucogallin as a novel aldose reductase inhibitor from Emblica officinalis. PloS One, 2012, 7(4), e31399.

[16] Lu, L.C.; Zhou, W.; Li, Z.H.; Yu, C.P.; Li, C.W.; Luo, M.H.; Xie, H. Effects of arctiin on streptozotocin-induced diabetic retinopathy in sprague-dawley rats. Planta. Med., 2012, 78(12), 1317-1323.

[17] Shi, X.; Liao, S.; Mi, H.; Guo, C.; Qi, D.; Li, F.; Zhang, C.; Yang, $\mathrm{Z}$. Hesperidin prevents retinal and plasma abnormalities in streptozotocin-induced diabetic rats. Molecules, 2012, 17(11), 1286812881.

[18] Silva, K.C.; Rosales, M.A.; Hamassaki, D.E.; Saito, K.C.; Faria, A.M.; Ribeiro, P.A.; Faria, J.B.; Faria, J.M. Green tea is neuroprotective in diabetic retinopathy. Invest. Ophthalmol. Vis. Sci., 2013, 54(2), 1325-1336.

[19] Kumar, B.; Gupta, S.K.; Nag, T.C.; Srivastava, S.; Saxena, R. Green tea prevents hyperglycemia-induced retinal oxidative stress and inflammation in streptozotocin-induced diabetic rats. Ophthalmic. Res., 2012, 47(2), 103-108.

[20] Zhang, L.; Dai, S.Z.; Nie, X.D.; Zhu, L.; Xing, F.; Wang, L.Y. Effect of Salvia miltiorrhiza on retinopathy. Asian. Pac. J. Trop. Med., 2013, 6(2), 145-149.

[21] Saraswat, M.; Suryanarayana, P.; Reddy, P.Y.; Patil, M.A.; Balakrishna, N.; Reddy, G.B. Antiglycating potential of Zingiber officinalis and delay of diabetic cataract in rats. Mol. Vis., 2010, 16, 1525-1537.

[22] Mai, T.T.; Yamaguchi, K.; Yamanaka, M.; Lam, N.T.; Otsuka, Y.; Chuyen, N.V. Protective and anticataract effects of the aqueous extract of Cleistocalyx operculatus flower buds on $\beta$-cells of streptozotocin-diabetic rats. J. Agric. Food. Chem., 2010, 58(7), 41624168.

[23] El-Sayyad, H.I.; El-Sherbiny, M.A.; Sobh, M.A.; Abou-El-Naga, A.M.; Ibrahim, M.A.; Mousa, S.A. Protective effects of Morus alba leaves extract on ocular functions of pups from diabetic and hypercholesterolemic mother rats. Int. J. Biol. Sci., 2011, 7(6), 715-728.

[24] Kumar Gupta, S.; Kumar, B.; Srinivasan, B.P.; Nag, T.C.; Srivastava, S.; Saxena, R.; Aggarwal, A. Retinoprotective effects of Moringa oleifera via antioxidant, anti-inflammatory, and antiangiogenic mechanisms in streptozotocin-induced diabetic rats. $J$. Ocul. Pharmacol. Ther., 2013, 29(4), 419-426.

[25] Onkaramurthy, M.; Veerapur, V.P.; Thippeswamy, B.S.; Reddy, T.N.; Rayappa, H.; Badami, S. Anti-diabetic and anti-cataract effects of Chromolaena odorata Linn. in streptozotocin-induced diabetic rats. J. Ethnopharmacol., 2013, 14 (1), 363-372.

[26] Sen, S.; Chen, S.; Wu, Y.; Feng, B.; Lui, E.K.; Chakrabarti, S. Preventive effects of north american ginseng (Panax quinquefolius) on diabetic retinopathy and cardiomyopathy. Phytother. Res., $\mathbf{2 0 1 3}$, 27(2), 290-298.

[27] Li, M.; Ma, Y.B.; Gao, H.Q.; Li, B.Y.; Cheng, M.; Xu, L.; Li, X.L.; Li, X.H. A novel approach of proteomics to study the mechanism of action of grape seed proanthocyanidin extracts on diabetic retinopathy in rats. Chin. Med. J., 2008, 121(24), 2544-2552.

[28] Song, M.K.; Salam, N.K.; Roufogalis, B.D.; Huang, T.H. Lycium barbarum (Goji berry) extracts and its taurine component inhibit PPAR- $\gamma$-dependent gene transcription in human retinal pigment epithelial cells: possible implications for diabetic retinopathy treatment. Biochem. Pharmacol., 2011, 82(9), 1209-1218.

[29] Hu, C.K.; Lee, Y.J.; Colitz, C.M.; Chang, C.J.; Lin, C.T. The protective effects of Lycium barbarum and Chrysanthemum morifolium on diabetic retinopathies in rats. Vet. Ophthalmol., 2012, 15 (Suppl 2), 65-71.

[30] Marwick, T.H. Diabetic heart disease. Heart, 2006, 92(3), 296-300.

[31] Yang, J.; Han, Y.; Sun, H.; Chen, C.; He, D.; Guo, J.; Yu, C.; Jiang, B.; Zhou, L.; Zeng, C. (-)-Epigallocatechin gallate suppresses proliferation of vascular smooth muscle cells induced by high glucose by inhibition of PKC and ERK1/2 signalings. J. Agric. Food. Chem., 2011, 59(21), 11483-11490.

[32] Yu, L.; Zhao, Y.; Fan, Y.; Wang, M.; Xu, S.; Fu, G. Epigallocatechin-3 gallate, a green tea catechin, attenuated the downregulation of the cardiac gap junction induced by high glucose in neonatal rat cardiomyocytes. Cell. Physiol. Biochem., 2010, 26(3), 403-412.

[33] Yuan, W.; Zhang, Y.; Ge, Y.; Yan, M.; Kuang, R.; Zheng, X. Astragaloside IV inhibits proliferation and promotes apoptosis in rat vascular smooth muscle cells under high glucose concentration in vitro. Planta. Med., 2008, 74(10), 1259-1264.

[34] Cao, G.; Cai, H.; Cai, B.; Tu, S. Effect of 5-hydroxymethylfurfural derived from processed Cornus officinalis on the prevention of high glucose-induced oxidative stress in human umbilical vein endothelial cells and its mechanism. Food. Chem., 2013, 140(1-2), 273-279.

[35] Mapanga, R.F.; Rajamani, U.; Dlamini, N.; Zungu-Edmondson, M.; Kelly-Laubscher, R.; Shafiullah, M.; Wahab, A.; Hasan, M.Y.; Fahim, M.A.; Rondeau, P.; Bourdon, E.; Essop, M.F. Oleanolic acid: a novel cardioprotective agent that blunts hyperglycemiainduced contractile dysfunction. PloS One, 2012, 7(10), e47322.

[36] Bao, H.; Chen, L. Icariin reduces mitochondrial oxidative stress injury in diabetic rat hearts. Zhongguo. Zhong. Yao. Za. Zhi., 2011, 36(11), 1503-1507.

[37] Palanisamy, N.; Venkataraman, A.C. Beneficial effect of genistein on lowering blood pressure and kidney toxicity in fructose-fed hypertensive rats. Br. J. Nutr., 2013, 109(10), 1806-1812.

[38] Wang, M.; Zhang, W.B.; Zhu, J.H.; Fu, G.S.; Zhou, B.Q. Breviscapine ameliorates cardiac dysfunction and regulates the myocardial $\mathrm{Ca}^{2+}$-cycling proteins in streptozotocin-induced diabetic rats. Acta. Diabetol., 2010, 47(Suppl 1), 209-218.

[39] Shen, L.; You, B.A.; Gao, H.Q.; Li, B.Y.; Yu, F.; Pei, F. Effects of phlorizin on vascular complications in diabetes $\mathrm{db} / \mathrm{db}$ mice. Chin. Med. J., 2012, 125(20), 3692-3696.

[40] Sotnikova, R.; Okruhlicova, L.; Vlkovicova, J.; Navarova, J.; Gajdacova, B.; Pivackova, L.; Fialova, S.; Krenek, P. Rosmarinic acid administration attenuates diabetes-induced vascular dysfunction of the rat aorta. J. Pharm. Pharmacol., 2013, 65(5), 713-723.

[41] Moon, M.K.; Kang, D.G.; Lee, Y.J.; Kim, J.S.; Lee, H.S. Effect of Benincasa hispida Cogniaux. on high glucose-induced vascular inflammation of human umbilical vein endothelial cells. Vascul. Pharmacol., 2009, 50(3-4), 116-122.

[42] Lee, Y.J.; Kim, J.S.; Kang, D.G.; Lee, H.S. Buddleja officinalis suppresses high glucose-induced vascular smooth muscle cell proliferation: role of mitogen-activated protein kinases, nuclear factorkappa B and matrix metalloproteinases. Exp. Biol. Med., 2010, 235(2), 247-255.

[43] Qian, S.; Huo, D.; Wang, S.; Qian, Q. Inhibition of glucoseinduced vascular endothelial growth factor expression by Salvia miltiorrhiza hydrophilic extract in human microvascular endothelial cells: evidence for mitochondrial oxidative stress. J. Ethnopharmacol., 2011, 137(2), 985-991.

[44] Yu, J.; Fei, J.; Azad, J.; Gong, M.; Lan, Y.; Chen, G. Myocardial protection by Salvia miltiorrhiza injection in streptozotocininduced diabetic rats through attenuation of expression of thrombospondin-1 and transforming growth factor- $\beta 1$. J. Int. Med. Res., 2012, 40(3), 1016-1024.

[45] Chen, W.; Xia, Y.P.; Chen, W.J.; Yu, M.H.; Li, Y.M.; Ye, H.Y. Improvement of myocardial glycolipid metabolic disorder in diabetic hamster with Astragalus polysaccharides treatment. Mol. Biol. Rep., 2012, 39(7), 7609-7615.

[46] Chen, W.; Yu, M.H.; Li, Y.M.; Chen, W.J.; Xia, Y.P. Beneficial effects of Astragalus polysaccharides treatment on cardiac chymase activities and cardiomyopathy in diabetic hamsters. Acta. Diabetol., 2010, 47(Suppl 1), 35-46.

[47] Chen, W.; Li, Y.M.; Yu, M.H. Astragalus polysaccharides inhibited diabetic cardiomyopathy in hamsters depending on suppression of heart chymase activation. J. Diabetes. Complications., 2010, 24(3), 199-208.

[48] Jain, N.; Vijayaraghavan, R.; Pant, S.C.; Lomash, V.; Ali, M. Aloe vera gel alleviates cardiotoxicity in streptozocin-induced diabetes in rats. J. Pharm. Pharmacol., 2010, 62(1), 115-123.

[49] Bhatti, R.; Sharma, S.; Singh, J.; Ishar, M.P. Ameliorative effect of Aegle marmelos leaf extract on early stage alloxan-induced diabetic cardiomyopathy in rats. Pharm. Biol., 2011, 49(11), 1137-1143.

[50] Huisamen, B.; George, C.; Dietrich, D.; Genade, S. Cardioprotective and anti-hypertensive effects of Prosopis glandulosa in rat models of pre-diabetes. Cardiovasc. J. Afr., 2013, 24(2), 10-16.

[51] Ojezele, M.O.; Abatan, O.M. Hypoglycaemic and coronary risk index lowering effects of Bauhinia thoningii in alloxan induced diabetic rats. Afr. Health. Sci., 2011, 11(1), 85-89.

[52] Yang, M.; Xu, Z.; Zhang, R.; Zhang, P.; Weng, Y.; Shen, Y.; Zhang, X. Protection of myocardium in streptozotocin-induced diabetic rats by water extracts of hsian-tsao (Mesona procumbens Hems1.). Asian. Pac. J. Clin. Nutr., 2008, 17(1), 23-29. 
[53] Xi, S.; Zhou, G.; Zhang, X.; Zhang, W.; Cai, L.; Zhao, C. Protective effect of total aralosides of Aralia elata (Miq) Seem (TASAES) against diabetic cardiomyopathy in rats during the early stage, and possible mechanisms. Exp. Mol. Med., 2009, 41(8), 538547.

[54] Sharma, S.B.; Tanwar, R.S.; Rini, A.C.; Singh, U.R.; Gupta, S.; Shukla, S.K. Protective effect of Morus rubra L. leaf extract on diet-induced atherosclerosis in diabetic rats. Indian. J. Biochem. Biophys., 2010, 47(1), 26-31.

[55] Huang, T.H.; He, L.; Qin, Q.; Yang, Q.; Peng, G.; Harada, M.; Qi, Y.; Yamahara, J.; Roufogalis, B.D.; Li, Y. Salacia oblonga root decreases cardiac hypertrophy in zucker diabetic fatty rats: inhibition of cardiac expression of angiotensin II type 1 receptor. Diabetes. Obes. Metab., 2008, 10(7), 574-585.

[56] Ge, M.; Ma, S.; Tao, L.; Guan, S. The effect of gypenosides on cardiac function and expression of cytoskeletal genes of myocardium in diabetic cardiomyopathy rats. Am. J. Chinese. Med., 2009, 37(06), 1059-1068.

[57] Pang, X.; Zhao, J.; Zhang, W.; Zhuang, X.; Wang, J.; Xu, R.; Xu, Z.; Qu, W. Antihypertensive effect of total flavones extracted from seed residues of Hippophae rhamnoides L. in sucrose-fed rats. J. Ethnopharmacol., 2008, 117(2), 325-331.

[58] Soman, S.; Rajamanickam, C.; Rauf, A.A.; Indira, M. Beneficial effects of Psidium guajava leaf extract on diabetic myocardium. Exp. Toxicol. Pathol., 2013, 65(1-2), 91-95.

[59] Nocun, M.; Ulicna, O.; Muchova, J.; Durackova, Z.; Watala, C. French maritime pine bark extract (pycnogenol) reduces thromboxane generation in blood from diabetic male rats. Biomed. Pharmacother., 2008, 62(3), 168-172.

[60] Raja, L.; Palanivelu, S.; Panchanatham, S. Anti-inflammatory property of Kalpaamruthaa on myocardium in type 2 diabetes mellitus induced cardiovascular complication. Immunopharmacol. Immunotoxicol., 2013, 35(1), 119-125.

[61] Latha, R.; Shanthi, P.; Sachdanandam, P. Kalpaamruthaa ameliorates myocardial and aortic damage in cardiovascular complications associated with type 2 diabetes mellitus. Can. J. Physiol. Pharmacol., 2013, 91(2), 116-123.

[62] Ni, Q.; Wang, J.; Li, E.Q.; Zhao, A.B.; Yu, B. Wang, M.; Huang, C.R. Study on the protective effect of Shengmai San on the myocardium in the type 2 diabetic cardiomyopathy model rat. J. Tradit. Chin. Med., 2011, 31(3), 209-219.

[63] Ni, Q.; Wang, J.; Li, E.Q.; Zhao, A.B.; Yu, B.; Wang, M.; Huang, C.R. Study on the protective effect of the mixture of Shengmai powder and Danshen decoction on the myocardium of diabetic cardiomyopathy in the rat model. Chinese. J. Integr. Med., 2011, 17(2), 116-125.

[64] Romeo, L.; Intrieri, M.; D'Agata, V.; Mangano, N.G.; Oriani, G.; Ontario, M.L.; Scapagnini, G. The major green tea polyphenol, (-)epigallocatechin-3-gallate, induces heme oxygenase in rat neurons and acts as an effective neuroprotective agent against oxidative stress. J. Am. Coll. Nutr., 2009, 28 (sup 4), 492S-499S.

[65] Liu, Y.; Wang, L.; Li, X.; Lv, C.; Feng, D.; Luo, Z. Tanshinone IIA improves impaired nerve functions in experimental diabetic rats. Biochem. Biophys. Res. Commun., 2010, 399(1), 49-54.

[66] Kandhare, A.D.; Raygude, K.S.; Ghosh, P.; Ghule, A.E.; Bodhankar, S.L. Neuroprotective effect of naringin by modulation of endogenous biomarkers in streptozotocin induced painful diabetic neuropathy. Fitoterapia, 2012, 8 (4), 650-659.

[67] Nadig, P.D.; Revankar, R.R.; Dethe, S.M.; Narayanswamy, S.B.; Aliyar, M.A. Effect of Tinospora cordifolia on experimental diabetic neuropathy. Indian. J. Pharmacol., 2012, 44(5), 580-583.

[68] Comelli, F.; Bettoni, I.; Colleoni, M.; Giagnoni, G.; Costa, B. Beneficial effects of a Cannabis sativa extract treatment on diabetes-induced neuropathy and oxidative stress. Phytother. Res., 2009, 23(12), 1678-1684.

[69] Schneider, R.; Welt, K.; Aust, W.; Kluge, R.; Löster, H.; Fitzl, G. Cardiovascular autonomic neuropathy in spontaneously diabetic rats with and without application of Egb 761. Histol. Histopathol., 2010, 25(12), 1581-1590.

[70] da Silva, G.G.; Zanoni, J.N.; Buttow, N.C. Neuroprotective action of Ginkgo biloba on the enteric nervous system of diabetic rats. World. J. Gastroenterol., 2011, 17(7), 898-905.

[71] Taliyan, R.; Sharma, P.L. Protective effect and potential mechanism of Ginkgo biloba extract Egb 761 on STZ-induced neuropathic pain in rats. Phytother. Res., 2012, 26(12), 1823-1829.
[72] Zangiabadi, N.; Asadi-Shekaari, M.; Sheibani, V.; Jafari, M.; Shabani, M.; Asadi, A.R.; Tajadini, H.; Jarahi, M. Date fruit extract is a neuroprotective agent in diabetic peripheral neuropathy in streptozotocin-induced diabetic rats: a multimodal analysis. Oxid. Med. Cell. Longev., 2011, 2011 Article ID 976948.

[73] Cui, X.P.; Li, B.Y.; Gao, H.Q.; Wei, N.; Wang, W.L.; Lu, M. Effects of grape seed proanthocyanidin extracts on peripheral nerves in streptozocin-induced diabetic rats. J. Nutr. Sci. Vitaminol., 2008, 54(4), 321-328.

[74] Tiwari, V.; Kuhad, A.; Chopra, K. Emblica officinalis corrects functional, biochemical and molecular deficits in experimental diabetic neuropathy by targeting the oxido-nitrosative stress mediated inflammatory cascade. Phytother. Res., 2011, 25(10), 1527-1536.

[75] Watcho, P.; Stavniichuk, R.; Tane, P.; Shevalye, H.; Maksimchyk, Y.; Pacher, P.; Obrosova, I.G. Evaluation of PMI-5011, an ethanolic extract of Artemisia dracunculus L., on peripheral neuropathy in streptozotocin-diabetic mice. Int. J. Mol. Med., 2011, 27(3), 299307.

[76] Thorve, V.S.; Kshirsagar, A.D.; Vyawahare, N.S.; Thakurdesai, P.A.; Bhandare, A.M. H. Spinosa T. Anders ameliorates diabetic neuropathy in wistar albino rats. J. Complem. Integr. Med., 2012, 9 , Article 2.

[77] Khaliq, F.; Parveen, A.; Singh, S.; Hussain, M.E.; Fahim, M. Terminalia arjuna improves cardiovascular autonomic neuropathy in streptozotocin-induced diabetic rats. Cardiovasc. Toxicol., 2013, 13(1), 68-76.

[78] Hong, B.N.; Yi, T.H.; Park, R.; Kim, S.Y.; Kang, T.H. Coffee improves auditory neuropathy in diabetic mice. Neurosci. Lett., 2008, 441(3), 302-306.

[79] Liu, Q.S.; Pang, Z.R.; Liu, R.; He, G.R.; Cui, J.; Yin, X.Y. Effective compounds group of Mongolian prescriptions Baimai-San protect against peripheral neuropathy in lower limbs of rats through neuroprotective effect. J. Ethnopharmacol., 2011, 135(3), 786-791.

[80] Hamdy, N.M.; Taha, R.A. Effects of Nigella sativa oil and thymoquinone on oxidative stress and neuropathy in streptozotocininduced diabetic rats. Pharmacology, 2009, 84(3), 127-134.

[81] Omran, O.M. Histopathological study of evening primrose oil effects on experimental diabetic neuropathy. Ultrastruct. Pathol., 2012, 36(4), 222-227.

[82] Lee, M.J.; Rao, Y.K.; Chen, K.; Lee, Y.C.; Chung, Y.S.; Tzeng, Y.M. Andrographolide and 14-deoxy-11,12-didehydroandrographolide from Andrographis paniculata attenuate high glucoseinduced fibrosis and apoptosis in murine renal mesangeal cell lines. J. Ethnopharmacol., 2010, 132(2), 497-505.

[83] Huang, J.S.; Chuang, L.Y.; Guh, J.Y.; Yang, Y.L.; Hsu, M.S. Effect of taurine on advanced glycation end products-induced hypertrophy in renal tubular epithelial cells. Toxicol. Appl. Pharmacol., 2008, 233(2), 220-226.

[84] Liu, J.P.; Feng, L.; Zhu, M.M.; Wang, R.S.; Zhang, M.H.; Hu, S.Y.; Jia, X.B.; Wu, J.J. The in vitro protective effects of curcumin and demethoxycurcumin in Curcuma longa extract on advanced glycation end products-induced mesangial cell apoptosis and oxidative stress. Planta. Med., 2012, 78(16), 1757-1760.

[85] Yu, D.Q.; Gao, Y.; Liu, X.H. Effects of rhein on the hypertrophy of renal proximal tubular epithelial cells induced by high glucose and angiotensin II in rats. Zhong. Yao. Cai., 2010, 33(4), 570-574.

[86] Park, C.H.; Noh, J.S.; Tanaka, T.; Yokozawa, T. 7-O-galloyl-D-sedoheptulose ameliorates renal damage triggered by reactive oxygen species-sensitive pathway of inflammation and apoptosis. J. Pharm. Pharmacol., 2012, 64(12), 1730-1740.

[87] Yamabe, N.; Kang, K.S.; Park, C.H.; Tanaka, T.; Yokozawa, T. 7-O-galloyl-D-sedoheptulose is a novel therapeutic agent against oxidative stress and advanced glycation endproducts in the diabetic kidney. Biol. Pharm. Bull., 2009, 32(4), 657-664.

[88] Chao, C.Y.; Mong, M.C.; Chan, K.C.; Yin, M.C. Anti-glycative and anti-inflammatory effects of caffeic acid and ellagic acid in kidney of diabetic mice. Mol. Nutr. Food. Res., 2010, 54(3), 388395.

[89] Zheng, N.; Lin, X.; Wen, Q.; Kintoko.; Zhang, S.; Huang, J.; Xu, X.; Huang, R. Effect of 2-dodecyl-6-methoxycyclohexa-2, 5-diene1, 4-dione, isolated from Averrhoa carambola L.(Oxalidaceae) roots, on advanced glycation end-product-mediated renal injury in type 2 diabetic KKAy mice. Toxicol. Lett., 2013, 219(1), 77-84.

[90] Li, G.S.; Jiang, W.L.; Yue, X.D.; Qu, G.W.; Tian, J.W.; Wu, J.; Fu, F.H. Effect of astilbin on experimental diabetic nephropathy in vivo and in vitro. Planta. Med., 2009, 75(14), 1470-1475. 
[91] Chennasamudram, S.P.; Kudugunti, S.; Boreddy, P.R.; Moridani, M.Y.; Vasylyeva, T.L. Renoprotective effects of (+)-catechin in streptozotocin-induced diabetic rat model. Nutr. Res., 2012, 32(5), 347-356.

[92] Zhou, Y.; Wang, F.; Hao, L.; Wang, N. Effects of magnoline on Pselectin's expression in diabetic rats and its reno-protection. Kidney. Blood. Press. Res., 2013, 37(2-3), 211-220.

[93] Qi, M.Y.; Kai-Chen.; Liu, H.R.; Su, Y.H.; Yu, S.Q. Protective effect of icariin on the early stage of experimental diabetic nephropathy induced by streptozotocin via modulating transforming growth factor $\beta 1$ and type IV collagen expression in rats. J. Ethnopharmacol., 2011, 138(3), 731-736.

[94] Yang, Q.H.; Liang, Y.; Xu, Q.; Zhang, Y.; Xiao, L.; Si, L.Y. Protective effect of tetramethylpyrazine isolated from Ligusticum chuanxiong on nephropathy in rats with streptozotocin-induced diabetes. Phytomedicine, 2011, 18(13), 1148-1152.

[95] Mapanga, R.F.; Tufts, M.A.; Shode, F.O.; Musabayane, C.T. Renal effects of plant-derived oleanolic acid in streptozotocin-induced diabetic rats. Renal. Fail., 2009, 31(6), 481-491.

[96] Zhang, Z.; Li, B.Y.; Li, X.L.; Cheng, M.; Yu, F.; Lu, W.D.; Cai, Q.; Wang, J.F.; Zhou, R.H.; Gao, H.Q. Proteomic analysis of kidney and protective effects of grape seed procyanidin B2 in $\mathrm{db} / \mathrm{db}$ mice indicate MFG-E8 as a key molecule in the development of diabetic nephropathy. BBA-Mol. Basis. Dis., 2013, 1832(6), 805816.

[97] Ma, X.; Xie, X.; Zuo, C.; Fan, J. Effects of ginsenoside Rg1 on streptozocin-induced diabetic nephropathy in rats. Sheng. Wu. Yi. Xue. Gong. Cheng. Xue. Za. Zhi., 2010, 27(2), 342-347.

[98] Jung, D.H.; Kim, Y.S.; Kim, N.H.; Lee, J.; Jang, D.S.; Kim, J.S. Extract of Cassiae semen and its major compound inhibits S100binduced TGF- $\beta 1$ and fibronectin expression in mouse glomerular mesangial cells. Eur. J Pharmacol., 2010, 641(1), 7-14.

[99] Kang, M.Y.; Park, Y.H.; Kim, B.S.; Seo, S.Y.; Jeong, B.C.; Kim, J.I.; Kim, H.H. Preventive effects of green tea (Camellia sinensis var. assamica) on diabetic nephropathy. Yonsei. Med. J., 2012, 53(1), 138-144.

[100] Ribaldo, P.D.; Souza, D.S.; Biswas, S.K.; Block, K.; Lopes de Faria, J.M.; Lopes de Faria, J.B. Green tea (Camellia sinensis) attenuates nephropathy by downregulating Nox4 NADPH oxidase in diabetic spontaneously hypertensive rats. J. Nutr., 2009, 139(1), 96-100.

[101] Perez Gutierrez, R.M.; Flores Cotera, L.B.; Gonzalez, A.M. Evaluation of the antioxidant and anti-glication effects of the hexane extract from Piper auritum leaves in vitro and beneficial activity on oxidative stress and advanced glycation end-productmediated renal injury in streptozotocin-treated diabetic rats. Molecules, 2012, 17(10), 11897-11919.

[102] Zhang, H.; Sun, W.; Wan, Y.; Che, X.; He, F.; Pu, H.; Dou, C. Preventive effects of multi-glycoside of Tripterygium wilfordii on glomerular lesions in experimental diabetic nephropathy. Zhongguo. Zhong, Yao. Za. Zhi., 2010, 35(11), 1460-1465.

[103] Mishra, A.; Bhatti, R.; Singh, A.; Singh Ishar, M.P. Ameliorative effect of the cinnamon oil from Cinnamomum zeylanicum upon early stage diabetic nephropathy. Planta. Med., 2010, 76(5), 412417.

[104] Oluwole Busayo, A.; Laura, Z.; Olufunke Olubusola, D.; Oluwafunmike Sharon, A.; Luciana, D.; Ezekiel Ademola, C.M. Ameliorative effects of ethanolic leaf extract of Azadirachta indica on renal histologic alterations in streptozotocin-induced diabetic rats. Am. J. Chin. Med., 2011, 39(5), 903-916.

[105] Lee, A.S.; Lee, Y.J.; Lee, S.M.; Yoon, J.J.; Kim, J.S.; Kang, D.G.; Lee, H.S. An aqueous extract of Portulaca oleracea ameliorates diabetic nephropathy through suppression of renal fibrosis and inflammation in diabetic db/db mice. Am. J. Chin. Med., 2012, 40(3), 495-510.

[106] Liu, I.M.; Tzeng, T.F.; Liou, S.S.; Chang, C.J. Angelica acutiloba root alleviates advanced glycation end-product-mediated renal injury in streptozotocin-diabetic rats. J. Food. Sci., 2011, 76(7), H165-H174.

[107] Shiju, T.M.; Rajkumar, R.; Rajesh, N.G.; Viswanathan, P. Aqueous extract of Allium sativum L. bulbs offer nephroprotection by attenuating vascular endothelial growth factor and extracellular signal regulated kinase-1 expression in diabetic rats. Indian. J. Exp. Biol., 2013, 51(2), 139-148.
[108] Shiju, T.M.; Rajesh, N.G.; Viswanathan, P. Renoprotective effect of aged garlic extract in streptozotocin-induced diabetic rats. Indian. J. Pharmacol., 2013, 45(1), 18-23.

[109] Sefi, M.; Fetoui, H.; Soudani, N.; Chtourou, Y.; Makni, M.; Zeghal, N. Artemisia campestris leaf extract alleviates early diabetic nephropathy in rats by inhibiting protein oxidation and nitric oxide end products. Pathol. Res. Pract., 2012, 20(3), 157-162.

[110] Somania, R.; Singhai, A.K.; Shivgunde, P.; Jain, D. Asparagus racemosus Willd. (Liliaceae) ameliorates early diabetic nephropathy in STZ induced diabetic rats. Indian. J. Exp. Biol., 2012, 50(7), 469-475.

[111] Bhatti, R.; Sharma, S.; Singh, J.; Singh, A.; Ishar, M.P. Effect of Aegle marmelos (L.) Correa on alloxan induced early stage diabetic nephropathy in rats. Indian. J. Exp. Biol., 2013, 51(6), 464-469.

[112] Kataya, H.H.; Hamza, A.A.; Ramadan, G.A.; Khasawneh, M.A. Effect of licorice extract on the complications of diabetes nephropathy in rats. Drug. Chem. Toxicol., 2011, 34(2), 101-108.

[113] Adewole, S.O.; Ojo, S.K.; Adenowo, T.K.; Salako, A.A.; Naicker, T.; Ojewole, J.A. Effects of Ficus exasperata Vahl. (Moraceae) leaf aqueous extract on the renal function of streptozotocin-treated rats. Folia. Morphol., 2012, 71(1), 1-9.

[114] Mansouri, E.; Panahi, M.; Ghaffari, M.A.; Ghorbani, A. Effects of grape seed proanthocyanidin extract on oxidative stress induced by diabetes in rat kidney. Iran. Biomed. J., 2011, 15(3), 100-106.

[115] Ramudu, S.K.; Korivi, M.; Kesireddy, N.; Lee, L.C.; Cheng, I.S.; Kuo, C.H.; Kesireddy, S.R. Nephro-protective effects of a ginger extract on cytosolic and mitochondrial enzymes against streptozotocin (STZ)-induced diabetic complications in rats. Chin. J. Physiol., 2011, 54(2), 79-86.

[116] Lee, W.C.; Wang, C.J.; Chen, Y.H.; Hsu, J.D.; Cheng, S.Y.; Chen, H.C.; Lee, H.J. Polyphenol extracts from Hibiscus sabdariffa Linnaeus attenuate nephropathy in experimental type 1 diabetes. $J$. $A g$ ric. Food. Chem., 2009, 57(6), 2206-2210.

[117] Sen, S.; Chen, S.; Feng, B.; Wu, Y.; Lui, E.; Chakrabarti, S. Preventive effects of north american ginseng (Panax quinquefolium) on diabetic nephropathy. Phytomedicine, 2012, 19(6), 494-505.

[118] Ramkumar, K.M.; Ponmanickam, P.; Velayuthaprabhu, S.; Archunan, G.; Rajaguru, P. Protective effect of Gymnema montanum against renal damage in experimental diabetic rats. Food. Chem. Toxicol., 2009, 47(10), 2516-2521.

[119] Honoré, S.M.; Cabrera, W.M.; Genta, S.B.; Sánchez, S.S. Protective effect of yacon leaves decoction against early nephropathy in experimental diabetic rats. Food. Chem. Toxicol., 2012, 50(5), 1704-1715.

[120] Yang, M.; Xu, Z.P.; Xu, C.J.; Meng, J.; Ding, G.Q.; Zhang, X.M.; Weng, Y. Renal protective activity of Hsian-tsao extracts in diabetic rats. Biomed. Environ. Sci., 2008, 21(3), 222-227.

[121] Zhou, Y.; Liao, Q.; Luo, Y.; Qing, Z.; Zhang, Q.; He, G. Renal protective effect of Rosa laevigata Michx. by the inhibition of oxidative stress in streptozotocin-induced diabetic rats. Mol. Med. Rep., 2012, 5(6), 1548-1554.

[122] Lin, C.Y.; Yin, M.C. Renal protective effects of extracts from guava fruit (Psidium guajava L.) in diabetic mice. Plant. Foods. Hum. Nutr., 2012, 67(3), 303-308.

[123] Kuang, Q.T.; Zhao, J.J.; Ye, C.L.; Wang, J.R.; Ye, K.H.; Zhang, X.Q.; Wang, Y.; Ye, W.C. Nephro-protective effects of total triterpenoids from Psidium guajava leaves on type 2 diabetic rats. Zhong. Yao. Cai., 2012, 35(1), 94-97.

[124] Zhang, M.; Liu, M.; Xiong, M.; Gong, J.; Tan, X. Schisandra chinensis fruit extract attenuates albuminuria and protects podocyte integrity in a mouse model of streptozotocin-induced diabetic nephropathy. J. Ethnopharmacol., 2012, 141(1), 111-118.

[125] Lee, S.H.; Kim, Y.S.; Lee, S.J.; Lee, B.C. The protective effect of Salvia miltiorrhiza in an animal model of early experimentally induced diabetic nephropathy. J. Ethnopharmacol., 2011, 137(3), 1409-1414.

[126] Sadiq, S.; Nagi, A.H.; Shahzad, M.; Zia, A. The reno-protective effect of aqueous extract of Carum carvi (black zeera) seeds in streptozotocin induced diabetic nephropathy in rodents. Saudi. J. Kidney. Dis. Transpl., 2010, 21(6), 1058-1065.

[127] Omara, E.A.; Nada, S.A.; Farrag, A.R.H.; Sharaf, W.M.; ElToumy, S.A. Therapeutic effect of Acacia nilotica pods extract on streptozotocin induced diabetic nephropathy in rat. Phytomedicine, 2012, $19(12), 1059-1067$. 
[128] Xue, W.; Lei, J.; Li, X.; Zhang, R. Trigonella foenum graecum seed extract protects kidney function and morphology in diabetic rats via its antioxidant activity. Nutr. Res., 2011, 31(7), 555-562.

[129] Yang, L.; Ma, X.; Cheng, T.; Liu, T.; Wu, L.; Sun, W.; Joseph, M.P. Effect of Tangnaikang on TGF- $\beta 1$-induced transdifferentiation of human renal tubular epithelial HK-2 cells. J. Tradit. Chin. Med., 2013, 33(3), 388-393.

[130] Chen, P.; Wan, Y.; Wang, C.; Zhao, Q.; Wei, Q.; Tu, Y.; Yin, X. Mechanisms and effects of Abelmoschus manihot preparations in treating chronic kidney disease. Zhongguo. Zhong. Yao. Za. Zhi., 2012, 37(15), 2252-2256.

[131] Sonawane, R.D.; Vishwakarma, S.L.; Lakshmi, S.; Rajani, M.; Padh, H.; Goyal, R.K. Amelioration of STZ-induced type 1 diabetic nephropathy by aqueous extract of Enicostemma littorale Blume. and swertiamarin in rats. Mol. Cell. Biochem., 2010, 340(1-2), 1-6.

[132] Siddiqui, S.; Rashid Khan, M.; Siddiqui, W.A. Comparative hypoglycemic and nephroprotective effects of tocotrienol rich fraction (TRF) from palm oil and rice bran oil against hyperglycemia induced nephropathy in type 1 diabetic rats. Chem-Biol. Interact., 2010, 188(3), 651-658.

[133] Orsolic, N.; Sirovina, D.; Koncic, M.Z.; Lackovic, G.; Gregorovic, G. Effect of Croatian propolis on diabetic nephropathy and liver toxicity in mice. BMC Complement. Altern. Med., 2012, 12, 117.

[134] Zhang, Y.; Zhang, D.; Zhang, M. Inhibition mechanism of compound ethanol extracts from wuweizi (Fructus schisandrae chinensis) on renal interstitial fibrosis in diabetic nephropathy model mice. J. Tradit. Chin. Med., 2012, 32(4), 669-673.

[135] Steigerwalt, R.; Nebbioso, M.; Appendino, G.; Belcaro, G.; Ciammaichella, G.; Cornelli, U.; Luzzi, R.; Togni, S.; Dugall, M.; Cesarone, M.R.; Ippolito, E.; Errichi, B.M.; Ledda, A.; Hosoi, M.; Corsi, M. Meriva ${ }^{\circledR}$, a lecithinized curcumin delivery system, in diabetic microangiopathy and retinopathy. Panminerva. Med., 2012, 54(1 Suppl 4), 11-16.

[136] Luo, X.X.; Duan, J.G.; Liao, P.Z.; Wu, L.; Yu, Y.G.; Qiu, B.; Wang, Y.L.; Li, Y.M.; Yin, Z.Q.; Liu, X.L.; Yao, K. Effect of qiming granule on retinal blood circulation of diabetic retinopathy: a multicenter clinical trial. Chin. J. Integr. Med., 2009, 15(5), 384388.

[137] Qian, S.; Wang, S.; Fan, P.; Huo, D.; Dai, L.; Qian, Q. Effect of Salvia miltiorrhiza hydrophilic extract on the endothelial biomarkers in diabetic patients with chronic artery disease. Phytother. Res., 2012, 26(10), 1575-1578.

[138] Qian, Q.; Qian, S.; Fan, P.; Huo, D.; Wang, S. Effect of Salvia miltiorrhiza hydrophilic extract on antioxidant enzymes in diabetic patients with chronic heart disease: a randomized controlled trial. Phytother. Res., 2012, 26(1), 60-66.

[139] Mozaffari-Khosravi, H.; Jalali-Khanabadi, B.A.; AfkhamiArdekani, M.; Fatehi, F.; Noori-Shadkam, M. The effects of sour tea (Hibiscus sabdariffa) on hypertension in patients with type II diabetes. J. Hum. Hypertens., 2008, 23(1), 48-54.

[140] Mozaffari-Khosravi, H.; Ahadi, Z.; Barzegar, K. The effect of green tea and sour tea on blood pressure of patients with type 2 diabetes: a randomized clinical trial. J. Diet. Suppl., 2013, 10(2), $105-115$.

[141] Mucalo, I.; Jovanovski, E.; Rahelić, D.; Božikov, V.; Romić, Z.; Vuksan, V. Effect of american ginseng (Panax quinquefolius L.) on arterial stiffness in subjects with type-2 diabetes and concomitant hypertension. J. Ethnopharmacol., 2013, 150(1), 148-153.

[142] Shidfar, F.; Froghifar, N.; Vafa, M.; Rajab, A.; Hosseini, S.; Shidfar, S.; Gohari, M. The effects of tomato consumption on serum glucose, apolipoprotein B, apolipoprotein A-1, homocysteine and blood pressure in type 2 diabetic patients. Int. J. Food. Sci. Nutr., 2011, 62(3), 289-294.

[143] Kar, P.; Laight, D.; Rooprai, H.K.; Shaw, K.M.; Cummings, M. Effects of grape seed extract in type 2 diabetic subjects at high car- diovascular risk: a double blind randomized placebo controlled trial examining metabolic markers, vascular tone, inflammation, oxidative stress and insulin sensitivity. Diabetes. Med., 2009, 26(5), 526531.

[144] Fang, Z.H.; Liu, Y.; Bao, T.T.; Ni, Y.Q.; Liu, J.; Shi, G.B.; Wu, J.P.; Yang, J.P.; Zhang, H. Effect of Danzhijiangtang capsule on monocyte chemoattractant protein-1 mRNA expression in newly diagnosed diabetes subclinical vascular lesions. World. J. Gastroenterol., 2013, 19 (19), 2963-2968.

[145] Liu, D.; Tang, J.Y.; Yan, L. Effect of compound danshen dripping pill on arterial intima-media thickness in patients with newly diagnosed type 2 diabetes mellitus. Zhongguo. Zhong. Xi. Yi. Jie. He. Za. Zhi., 2010, 30(12), 1265-1268.

[146] Feng, K.; Tan, J.F.; Chen, Y. Treatment of lower extremity diabetic atherosclerotic obliterans with shuxuetong injection. Zhongguo. Zhong. Xi. Yi. Jie. He. Za. Zhi., 2009, 29(3), 255-257.

[147] Liu, Y.; Li, N.; Ran, X.W. Clinical effect of ligustrazine combined with citicoline for treatment of diabetic peripheral neuropathy. Zhongguo. Zhong. Xi. Yi. Jie. He. Za. Zhi., 2008, 28(7), 606-609.

[148] Motilal, S.; Maharaj, R.G. Nutmeg extracts for painful diabetic neuropathy: a randomized, double-blind, controlled study. J. Altern. Complem. Med., 2013, 19(4), 347-352.

[149] Selvarajah, D.; Gandhi, R.; Emery, C.J.; Tesfaye, S. Randomized placebo controlled double blind clinical trial of cannabis based medicinal product (sativex) in painful diabetic neuropathy: depression is a major confounding factor. Diabetes Care, 2010, 33(1), 128130 .

[150] Huang, P.J.; Mao, X.H.; Wang, Y.P. Electrophysiological changes in diabetic peripheral neuropathy patients of different chinese medicine syndrome types intervened by naoxintong and mecobalamin. Zhongguo. Zhong. Xi. Yi. Jie. He. Za. Zhi., 2011, 31(8), 1051-1056.

[151] Li, L. The effect of neuragen PN on neuropathic pain: a randomized, double blind, placebo controlled clinical trial. BMC. Complement. Altern. Med., 2010, $10(22), 1-7$.

[152] Singh, R.G.; Rathore, S.S.; Kumar, R.; Agarwal, A.; Dubey, G.P. Nephroprotective role of Salacia chinensis in diabetic CKD patients: A pilot study. Indian. J. Med. Sci., 2010, 64(8), 378-384.

[153] Singh, R.G.; Rajak, M.; Ghosh, B.; Usha.; Agrawal, A.; Dubey, G.P. Comparative evaluation of fosinopril and herbal drug Dioscorea bulbifera in patients of diabetic nephropathy. Saudi. J. Kidney. Dis. Transpl., 2013, 24(4), 737-742.

[154] Li, X.S.; Zheng, W.Y.; Lou, S.X.; Lu, X.W.; Ye, S.H. Effect of Ginkgo leaf extract on vascular endothelial function in patients with early stage diabetic nephropathy. Chin. J. Integr. Med., 2009, 15(1), 26-29.

[155] Tu, X.; Liu, F.; Jordan, J.B.; Ye, X.F.; Fu, P.; Wang, F.; Zhong, S. 'Huang qi elixir'for proteinuria in patients with diabetic nephropathy: a study protocol for a randomized controlled pilot trial. Trials, 2013, 14, 223-228.

[156] Wang, H.; Mu, W.; Zhai, J.; Xing, D.; Miao, S.; Wang, J.; Deng, Y.; Wang, N.; Chen, H.; Yang, H.; He, X.; Shang, H. The key role of shenyan kangfu tablets, a Chinese patent medicine for diabetic nephropathy: study protocol for a randomized, double-blind and placebo-controlled clinical trial. Trials, 2013, 14, 165-173.

[157] Wang, F.L.; Chen, Z.Q.; Wang, Y.H. Clinical observation of treating early diabetic nephropathy by qi supplementing, yin nourishing, blood stasis dispersing, collateral dredging recipe. Zhongguo. Zhong. Xi. Yi. Jie. He. Za. Zhi., 2012, 32(1), 35-38.

[158] Song, J.; Li, Y.H.; Yang, X.D. Effect of combined therapy with bailing capsule and benazepril on urinary albumin excretion rate and C-reactive protein in patients with early diabetic nephropathy. Zhongguo. Zhong. Xi. Yi. Jie. He. Za. Zhi., 2009, 29(9), 791-793.

Received: February 03, 2014

Revised: June 03, 2014

Accepted: June 19, 2014

(C) Sridhar et al.; Licensee Bentham Open.

This is an open access article licensed under the terms of the Creative Commons Attribution Non-Commercial License (http://creativecommons.org/licenses/by-nc/3.0/) which permits unrestricted, non-commercial use, distribution and reproduction in any medium, provided the work is properly cited. 